\title{
Evaluating the Transport-Mode-Specific Trade Effects of Different Transport Infrastructure Types
}

by

Jan Wessel

Institute of Transport Economics Münster

Working Paper

No. 27

February 2019 


\section{(c) Westfälische Wilhelms-Universität (WWU),}

Institute of Transport Economics, 2019

\section{Address}

Institut für Verkehrswissenschaft

Am Stadtgraben 9

D 48143 Münster, Germany

\section{Telephone}

+4925183-22994

\section{Fax}

+4925183-28395

\section{E-Mail}

verkehrswissenschaft@uni-muenster.de

\section{Website}

http://www.iv-muenster.de

All rights reserved.

Any reproduction, publication and reprint in the form of a different publication, whether printed or produced electronically, in whole or in part, is permitted only with the explicit written authorisation of the Westfälische Wilhelms-Universität, Institute of Transport Economics, or the author(s).

The views expressed in this paper do not necessarily reflect those of the Institute of Transport Economics or the WWU.

The Working Paper Series seeks to disseminate economic research work by the WWU, Institute of Transport Economics staff and visitors. Papers by researchers not affiliated with the WWU Institute of Transport Economics may also be considered for publication to the extent that they have been presented at research seminars/workshops organised by the institute.

The working papers published in the Series constitute work in progress circulated to stimulate discussion and critical comments. Views expressed represent exclusively the authors' own opinions.

The Series is managed by the Director of the Institute of Transport Economics. 


\title{
Evaluating the Transport-Mode-Specific Trade Effects of Different Transport Infrastructure Types
}

\author{
By JAN WESSEL*
}

\begin{abstract}
Both qualitative and quantitative improvements for five different transport infrastructure types are evaluated with respect to their transport-mode-specific trade effects. Strong trade increases are found for survey-based quality indicators of airport and railroad infrastructure. For road trade, the road density is more important than the quality of road infrastructure. Additionally, the infrastructure quality of transit countries is an important trade flow driver of the land transport modes road and railroad. For the analysis of these effects, I use a gravity equation model with European trade flows that are disaggregated over five different transport modes. In combination with the quality and quantity indicators for each corresponding type of transport infrastructure, it is possible to directly estimate the unique trade effects for each infrastructure type. Moreover, a novel cross-mode analysis is conducted to estimate interdependencies and cross-effects that exist between different transport infrastructure types and different transport modes.
\end{abstract}

Keywords: Transport Infrastructure, Bilateral Trade, Gravity Equations.

JEL:F14, F17, R40, O18

\section{Introduction}

A good infrastructure offers many benefits and can enable a region to thrive economically. The positive infrastructure effects include productivity increases (Aschauer, 1989), lower costs for firms (Nadiri and Mamuneas, 1994), higher output (Boarnet, 1998), and also increases in international trade flows (Limao and Venables, 2001). However, it should be noted that there may also be undesired effects of transport infrastructure investments. For example, these investments can lead to greater inequalities between regions within a country, thus creating a core-periphery structure (Puga, 2002). Consequently, the discussion on the economic effects of transport infrastructure is still open and it is therefore necessary to further analyze the links between transport infrastructure and such economic outcomes as international trade flows.

Besides empirical evidence, Lakshmanan (2011) provides a theoretical foundation for the positive effects of transport infrastructure investments on international trade flows. He argues that transport infrastructure investments can improve the freight and service markets, for example through lower costs and transport times, or through an increase in reliability and service provision. From this, various mechanisms and dynamic development effects follow, that ultimately increase total factor productivity (TFP) and Gross Domestic Product (GDP) growth. The most important of these effects are probably the gains from trade. Transportusing firms can gain better access to distant markets through improvements in

* University of Münster, Institute of Transport Economics, Am Stadtgraben 9, 48143 Münster, Germany. 
transport costs and time savings, as well as through the supply of new or better transport services. The influence of infrastructure on trade is further underlined by Bougheas et al. (1999), who develop a theoretical model to show that if both countries invest optimally in infrastructure, there is a positive relationship between the stock of infrastructure and the volume of bilateral trade.

Various studies have shown that international trade itself is also an important driver of economic performance, and can benefit countries, firms, and individuals. Besides higher growth rates (Harrison, 1996, Dollar and Kraay, 2003) and higher incomes (Frankel and Romer, 1999), international trade can raise average productivity and lower the average mark-ups of firms (Melitz and Ottaviano, 2008). Although the least productive firms ultimately leave the market, the size of remaining firms and even the product variety increases, resulting in overall welfare gains. Imports can also generate technological spillovers (Falvey et al. 2004), which in turn improve TFP and overall productivity (Alcalá and Ciccone, 2004). Moreover, Dollar and Kraay (2004) show that open trade regimes can lead to faster growth rates and also to a reduction of absolute poverty within poorer countries.

In order to shed more light on the differentiated relationships between international trade flows and certain types of transport infrastructure, this paper will focus on transport-mode specific trade effects that stem from changes in different types of transport infrastructure. For the analysis of these trade effects, I set up a gravity equation model with infrastructure variables and relevant control variables. To the best of my knowledge, previous gravity equation studies on infrastructure trade effects have focused only on aggregated international trade data, or analyzed trade flows of one specific transport mode without considering transport-mode-specific infrastructure. In this research paper, however, the trade-enhancing effects of transport infrastructure improvements are differentiated over five types of transport infrastructure: road, railroad, sea, waterway, and air. As different infrastructure types have their own features and characteristics, the trade effects should be unique for each.

In the existing literature, there is a variety of papers dealing with infrastructure trade effects. Below, these papers are divided into two categories. Papers in the first category focus on trade flows that are aggregated over all transport modes, whereas papers in the second category focus on specific transport modes. A more detailed review on infrastructure trade effects can, for example, be found in Celbis et al. (2014) or Ferrari et al. (2019).

One of the seminal papers belonging to the first category is by Limao and Venables (2001), who employ a gravity equation to show that transport infrastructure increases aggregated trade flows. A decline in infrastructure quality from the median to the 75 th percentile leads to a decline in trade volumes of 28 percentage points. Moreover, they observe that underdeveloped infrastructure in transit countries can impede trade flows. It should be noted that they also utilize transport costs of shipments from Baltimore, in order to show that transport infrastructure reduces transport costs. Wilson et al. (2005) estimate that there are also positive trade effects of port efficiency on aggregated trade flows of manufactured goods. Furthermore, Portugal-Perez and Wilson (2012) show that physical infrastructure can significantly increase aggregated international trade flows and that the effect on exports is the strongest. Francois and Manchin (2013) use principal component analysis to construct two indicators of infrastructure and obtain positive trade effects for both. Bensassi et al. (2015) shift the focus from the 
impact of transport infrastructure to that of logistics performance on aggregate trade flows. The authors demonstrate that there is a positive, causal relationship and that logistics are therefore an important determinant of international trade patterns.

The second category of papers analyzes specific transport modes. Duranton et al. (2014) evaluate the highway network in the United States, and find that a 1\% reduction in the highway travel distance between two cities increases the value of trade between these cities by $1.4 \%$ and the total weight by $1.9 \%$. For Colombia, Duranton (2015) finds a lower sensitivity of trade flows with respect to highway travel distances. A $10 \%$ increase in highway travel distance decreases the value of trade by $7 \%$ and the total weight by $6 \%$. Moreover, both studies find that withincity highways can affect the total weight of exports, but the value of exports is affected only in Colombia and not in the United States. Consequently, Duranton (2015) argues that within-city highways appear to affect the specialization of exports in cities of the United States, but not in Colombian cities. For Peru, Volpe Martincus et al. (2017) find evidence that new roads can increase firms' exports and, for Turkey, Coşar and Demir (2016) find that an increase in road capacities significantly increases trade flows. In addition to research on the road transport mode, there are also studies on transport via sea. With their measure of port efficiency, Sánchez et al. (2003) find that maritime transport costs decrease as efficiency rises. Blonigen and Wilson (2008) also find that port efficiency significantly increases trade volumes between ports in the United States and ports of other countries. For Brazil, Bottasso et al. (2018) show that an increase in port infrastructure strongly increases exports and that port infrastructure can also have positive, but less pronounced effects on imports. Clark et al. (2004), as well as Márquez-Ramos et al. (2011), estimate that maritime transport costs decrease with a better port infrastructure, and that transport costs (in a separate analysis) decrease bilateral maritime trade flows. Micco and Serebrisky (2004) observe a similar relationship for U.S. airport infrastructure and transport costs, specifically that airport infrastructure improvements from the 25th to the 75 th percentile can decrease transport costs by $15 \%$. Deviating from the strict definition of infrastructure, Alderighi and Gaggero (2017) demonstrate that the supply of non-stop flights also increases exports. This effect is driven mainly by fullservice carriers.

It should be noted that there are also papers that cannot be assigned strictly to one of the two aforementioned categories. Donaubauer et al. (2016), for example, construct an aggregate index of overall infrastructure that can be decomposed into the four subcomponents of transport infrastructure, information and communications technology (ICT) infrastructure, energy infrastructure, and financial infrastructure. They regress the overall indicator, as well as the subcomponents, on a measure of openness to trade. Transport infrastructure, as well as financial infrastructure, seem to have the largest trade effects of the four subcomponents. Gallego et al. (2015) model transport mode competition, but do not explicitly include an indicator variable for the quality or quantity of infrastructure. In addition, Llano et al. (2017) use intra-national trade flows of Spain that are disaggregated over four transport modes in order to model transport mode competition. They do not, however, include disaggregated indices of transport infrastructure in their analysis. Moreover, Martínez-Zarzoso et al. (2003) consider both sea and road trade flows in their analysis, but they use one aggregate infrastructure index that includes roads, paved roads, railroads and telephones. Martínez-Zarzoso 
et al. (2008) also consider sea and road trade flows and additionally include separate measures for road and port infrastructure. However, they only estimate the separate infrastructure effects on transport costs, but not on trade flows.

The importance of further analyzing transport-mode specific trade effects of different infrastructure types is underlined by Combes and Lafourcade (2005). They state that transport costs vary according to the different infrastructure types and transport vehicles that are used. This could be due to different energy consumption levels, operating costs, taxation, or the market structure of the different transport modes. Hummels (2007) also shows that factors like the distance between two trading partners can have different effects for different transport modes. Consequently, infrastructure trade effects should also vary over different transport modes. Because policymakers often have to decide which types of infrastructure should be improved and whether these improvements should be qualitative or quantitative, it is important to further analyze the exact effects of infrastructuretype-specific improvements.

Therefore, the data underlying this study are trade flows within the European Union (EU) that are disaggregated over five transport modes. In combination with infrastructure indicators at the transport-mode level, the estimation of trade effects should be more precise than for aggregated data. Furthermore, two different types of transport infrastructure variables are included in the model. This enables contrasting the trade effects of transport infrastructure quality indicators, which are based on surveys among logistic operators, with the trade effects of quantity indicators that rely on physical measures of infrastructure. Additionally, the infrastructure of transit countries is incorporated into the regression model for trade on roads, railroads, and sea. I use a map of Trans-European Transport Network (TEN-T) corridors to select plausible transit countries for the trading partners, and subsequently estimate the trade effects of transit country infrastructures, separated for each of the three transport modes. Last but not least, a cross-mode analysis is conducted in order to provide a novel and comprehensive overview of interdependencies between different transport infrastructure types and different transport modes.

The contribution of my analysis to the literature is fourfold: (i) transport infrastructure effects on international trade flows are calculated separately for each mode of transport and each corresponding infrastructure type, (ii) transport infrastructure trade effects are calculated separately for quality and quantity indicators of different transport infrastructure types, (iii) the transport infrastructure trade effects of transit countries are calculated for different transport modes, (iv) interdependencies and cross-effects between different transport infrastructure types and different transport modes are estimated.

The estimation results show that trade via air and rail offer the greatest potential for trade increases, if the quality of the corresponding infrastructure type is improved. Road trade, on the other hand, is more responsive to infrastructure quantity than to infrastructure quality. Furthermore, the infrastructure quality of transit countries strongly affects bilateral trade flows of the transport modes road and railroad, which highlights the importance and benefits of interregional infrastructure projects. Moreover, a novel cross-mode analysis reveals various interdependencies and cross-effects that exist between different infrastructure types and different transport modes.

These results could assist policymakers to more accurately calculate the trade effects of infrastructure projects. Subsequently, this might help in determining the 
best available infrastructure project for achieving the desired effects and might thus contribute to a more efficient use of public infrastructure expenditure.

The remainder of this paper is organized as follows. In Section III, the methodology of the gravity equation model and the data are presented. The regression results are outlined and checked for robustness in Section III. The results as well as policy implications and future research directions are discussed in Section IV. Section $\nabla$ concludes.

\section{Methodology and Data}

\section{A. Introducing the Gravity Equation Model}

In its most basic form, the gravity equation model states that trade flows between two countries depend on the economic masses of both countries, as well as on the distance between them. The first empirical estimation of a similar gravity equation model on international trade flows was conducted by Tinbergen (1962) and, subsequently, the gravity equation model became one of the most widely used tools for researchers analyzing international trade flows and their determinants (e.g. Matyas, 1997; McCallum, 1995; Anderson and van Wincoop, 2003). A theoretical foundation was provided by several authors, each using different models: Anderson (1979) used expenditure systems, Bergstrand (1985) a general equilibrium world trade model, and Deardorff (1998) showed that the gravity equation could be derived from two extreme cases of the Heckscher-Ohlin model. He further argued that simple forms of the gravity equation could possibly be derived from any plausible trade model. For a more detailed review of empirical and theoretical literature on gravity equation models, however, I refer to Head and Mayer (2014).

In order to derive a proper gravity equation setup for estimating infrastructure effects, it is very important to find suitable data on international trade as well as on infrastructure quality and quantity. Further, it is necessary to include control variables in the regression, so that omitted variable bias can be minimized. The control variables should account for the different factors that influence trade costs in order to isolate the trade effect that stems from transport infrastructure. An overview of the data used in this analysis can be found in Table A1 of Appendix A.

\section{B. Data}

\section{TRADE DATA}

The data on international trade flows are from Eurostat's Comext database 1 This dataset lists trade flows from $20 \mathrm{EU}$ reporting countries to all $28 \mathrm{EU}$ partner countries and differentiates these flows by their mode of transport. I restrict my analysis to exports of the transport modes road, railroad, sea, inland waterway, and air. Here, "the mode of transport corresponds to the active means of transport by which, on dispatch, the goods leave the national statistical territory of the exporting Member State and, on arrival, the goods enter the national statistical territory of the importing Member State" (Eurostat, 2016, p. 49). It should

Available under: http://epp.eurostat.ec.europa.eu/newxtweb/ Date of access and data extraction: 18th September 2018. 
be kept in mind that this definition does not strictly rule out the use of other transport modes in the overall transportation process. Nevertheless, the data can still serve as a good approximation of transport-mode-specific trade flows.

It should also be noted that the trade flows used in the analysis are exports. Infrastructure might be constructed in such a way that exports are benefitted more than imports and, consequently, the effect of a country's own infrastructure is larger on exports than on imports (Celbis et al., 2014). Measuring infrastructure effects for exports is thus the preferred option for this type of analysis as export flows can better capture the originally intended infrastructure effects.

The selected export flows are reported as Free On Board (FOB) values in current Euros. All in all, there are 540 pairs of reporting and partner countries and the trade flows are differentiated over five transport modes. The acquisition of these transport-mode-specific trade flows, which are essential for this type of analysis, has begun in 2010, therefore the data set used in this study spans the years from 2010 to 2017. This results in 21,600 unique observations. Following the recent literature in general and Francois and Manchin (2013) in particular, the remaining missing values can be set to zero. Ultimately, I have 6,215 values that are reported as zeros. This amounts to $6,215 / 21,600=28.77 \%$ of all observations ${ }^{2}$

\section{INFRASTRUCTURE VARIABLES}

Studies like Aschauer (1989), Canning (1998), Limao and Venables (2001), Portugal-Perez and Wilson (2012), Francois and Manchin (2013), and Donaubauer et al. (2016) use financial indicators or aggregated infrastructure indicators as approximations of infrastructure quality and quantity. For this study, however, the trade data are disaggregated over different transport modes, which is why transport infrastructure indicators at the level of the corresponding mode of transport are selected, in order to enable for a precise analysis of infrastructure trade effects. In the course of this analysis, a further differentiation is made between transport infrastructure quality and transport infrastructure quantity. As improvements in the quality of infrastructure might have different trade effects than increases in the quantity of infrastructure, this distinction can provide additional insights for infrastructure planners.

When analyzing the trade effects of transport infrastructure quality, I use the Global Competitiveness Report (GCR) of the World Economic Forum (WEF). The GCR offers indicators for the quality of road infrastructure, railroad infrastructure, port infrastructure, and air transport infrastructure. The indicators are based on surveys among logistic operators and employ a grading scale from 1 to 7. It should be noted that these indicators specifically refer to freight, and not to passenger transport. Thus, they offer a very good indication of the quality of different transport infrastructure types within a country. The latest installment of the GCR offers data from 2007 to 2017 (Schwab and Sala-i Martín, 2017). An overview of the qualities of road, railroad, seaport, and airport infrastructures of the EU countries in 2017 can be found in Figure 1. In general, Western European countries observe higher infrastructure qualities than Eastern European countries. The spatial variability of infrastructure qualities over different countries as well as the variability over different infrastructure types is used in order to estimate how

2 This percentage lies within reasonable boundaries. Francois and Manchin (2013) have $20 \%$ of zeros in their dataset, Helpman et al. (2008) roughly 50\%. The numbers and percentages of zero trade flows for each transport mode in my dataset are as follows: 614 (14.21\%) for Road; $1,317(30.49 \%)$ for Rail; 1,042 (24.12\%) for Sea; 3,109 (71.97\%) for Inland Waterway; and 133 (3.08\%) for Air. 
transport-mode-specific trade flows are influenced by the infrastructure types of the exporting and the importing country.

When looking at transport infrastructure quantity as opposed to quality, I use

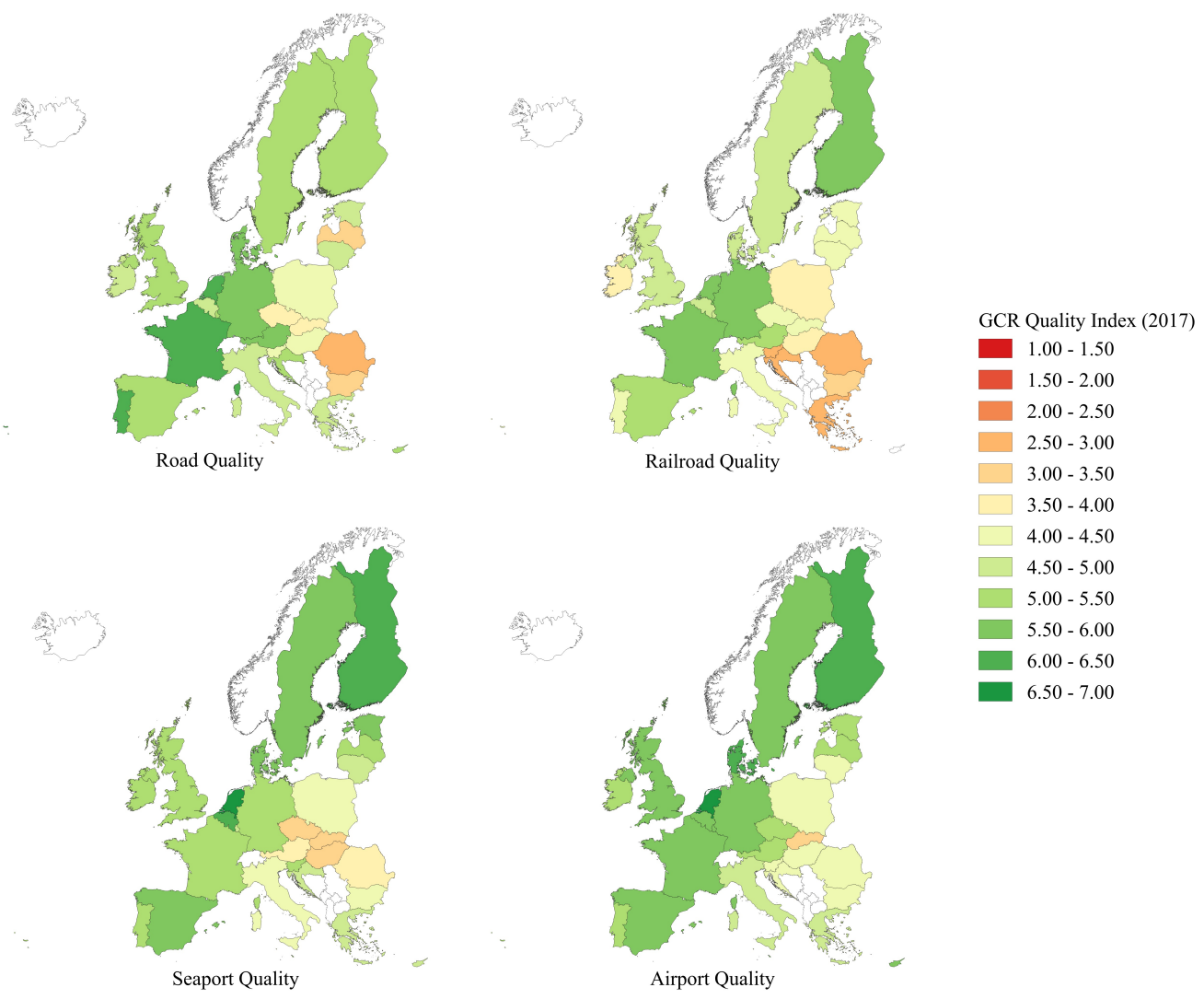

Figure 1. Overview of Infrastructure Qualities in 2017

different indicators of physical infrastructure from Eurostat. These indicators include the length of motorways within a country, the length of railway tracks, the length of navigable inland waterways, and the number of commercial airports (with more than 15,000 passenger units per year). Using the geographical area of a country, these figures are converted into densities of the type per $\mathrm{km}^{2}$. For sea trade, a quantitative index of port infrastructure from the United Nations Conference on Trade and Development (UNCTAD) is used. The so-called Liner Shipping Connectivity Index (LSCI) is a composite index of the number of ships, total container-carrying capacity of those ships, maximum vessel size, number of services, and the number of companies that operate container ships on services from and to a country's ports. Descriptive statistics for the infrastructure variables can be found in Table 1. As the aforementioned indicators can be rather stable over the course of the panel time frame, an overview of the countries with the smallest and the largest standard deviations over the considered time frame is presented in Table 2. Here, it can be seen that there are countries in which the quantity of certain infrastructure types has not changed over the considered years. Other countries, however, reveal moderate changes in their infrastructures. 
Table 1 -Descriptive Analysis of Infrastructure Variables

\begin{tabular}{lrrrrl}
\hline Variable & Mean & \multicolumn{1}{c}{ SD } & Minimum & \multicolumn{1}{c}{ Maximum } & Source \\
\hline airport_quality & 5.165 & 0.882 & $3.182(\mathrm{SVK})$ & 6.607 (DEU) & GCR \\
airport_quantity* & 0.217 & 0.575 & 0.016 (LVA) & 3.165 (MLT) & Eurostat \\
rail_quality & 4.346 & 1.050 & $2.244(\mathrm{ROU})$ & 6.475 (FRA) & GCR \\
rail_quantity* $_{\text {road_quality }}$ & 82.670 & 61.073 & $21.000(\mathrm{GRC})$ & 240.139 (LUX) & Eurostat \\
road_quantity* & 4.811 & 1.147 & 1.941 (ROU) & 6.599 (FRA) & GCR \\
seaport_quality $^{\text {seaport_quantity }}$ & 19.678 & 17.356 & 1.393 (ROU) & 65.834 (NLD) & Eurostat \\
waterway_quantity* $^{*}$ & 34.903 & 0.941 & 2.639 (ROU) & 6.809 (NLD) & GCR \\
\hline
\end{tabular}

Note: For minimum and maximum values, the corresponding ISO3 country code is given in brackets. DIV implies that more countries observe this particular value.

* To provide a better overview, the descriptive statistics of these variables are based on units of the type per $1,000 \mathrm{~km}^{2}$, whereas the regression models employ units of the type per $\mathrm{km}^{2}$.

\section{Control Variables}

In order to correctly isolate and estimate the effect of infrastructure on trade flows, it is necessary to include control variables in the regression, so that the omitted variable bias is minimized. These control variables need to account for various factors that influence trade costs and, subsequently, also trade flows. As there is an inherent trade-off between bias and variance when an additional variable enters the regression, it is advisable to include the most important variables, while at the same time not overloading the model. The selection of control variables is based roughly on Wilson et al. (2005), but also inspired by similar papers on gravity equation models and infrastructure (e.g. Limao and Venables, 2001; Portugal-Perez and Wilson, 2012, Francois and Manchin, 2013; Melitz and Toubal, 2014).

Besides GDP, I include GDP per capita in order to approximate the living standards of both the importing and the exporting country. The data for these two variables are from Eurostat and denoted in current Euros. Moreover, geographic aspects might influence the propensity to trade, so it is accounted for whether a country is an island ${ }^{3}$ (Source: Early, 2008) or whether a country is landlocked (Source: Mayer and Zignago, 2011). Following Wilson et al. (2005), control variables for the regulatory environment of both exporter and importer, and also for the customs environment of the importer, are included in the regression (Source: GCR).

Besides unilateral control variables, a bilateral control variable for the distance between two countries and a control variable that indicates contiguity are included (Source: Mayer and Zignago, 2011). Also, language similarity is accounted for (Source: Melitz and Toubal, 2014) and a dummy variable that accounts for the EU accession is included in the regression 4

Time-specific fixed effects can account for cyclical influences that are shared by all

The islands of the dataset are Cyprus, Great Britain, Ireland, and Malta.

Although the sample only consists of EU countries, Croatia was not a member of the EU at the beginning of the sample period. Thus, the effect that stems from Croatia's EU accession needs to be accounted for. 
Table 2-Minimum and Maximum Standard Deviations by Countries

\begin{tabular}{|c|c|c|}
\hline Variable & Minimum SD & Maximum SD \\
\hline airport_quality & $0.074($ FIN $)$ & 0.453 (EST) \\
\hline airport_quantity* & 0.000 (DIV) & $0.020(\mathrm{EST})$ \\
\hline rail_quality & 0.029 (AUT) & 0.425 (POL) \\
\hline rail_quantity* & 0.068 (SVK) & $16.536(\mathrm{HUN})$ \\
\hline road_quality & 0.096 (HUN) & $0.751(\mathrm{POL})$ \\
\hline road_quantity* & 0.000 (AUT) & $2.230(\mathrm{CZE})$ \\
\hline seaport_quality & $0.023(\mathrm{EST})$ & 0.554 (CZE) \\
\hline seaport_quantity & 0.000 (DIV) & 12.113 (POL) \\
\hline waterway_quantity* & 0.000 (DIV) & 1.595 (NLD) \\
\hline
\end{tabular}

Note: For minimum and maximum values, the corresponding ISO3 country code is given in brackets. DIV implies that more countries observe this particular value.

* To provide a better overview, the descriptive statistics of these variables are based on units of the type per $1,000 \mathrm{~km}^{2}$, whereas the regression models employ units of the type per $\mathrm{km}^{2}$.

countries. An inclusion of time-specific fixed effects in the regression is therefore advisable at all times (Egger and Pfaffermayr, 2003). In accordance with this finding and the majority of studies, time-specific fixed effects are included in each model specification.

\section{Transit COUNTRIES}

As outlined by Limao and Venables (2001) or Buys et al. (2010), the transport infrastructure of transit countries can be of great importance for international trade flows. Therefore, two kinds of transit country infrastructure variables are calculated, one for transport modes that rely on port infrastructure (sea and air transport) and one for land transport modes (road and railroad transport).

All countries of the EU have at least one airport, so that it is not necessary to create unilateral transit country infrastructure variables for air trade flows. However, not all EU countries have access to the sea. In a first step, transit countries are assigned to the five landlocked countries of the dataset. If possible, transit country assignments are taken from Limao and Venables (2001). Otherwise, I use a map of the main TEN-T corridors of the EU and select the nearest country that could be used as a transit country for maritime transport flows 5 In a second step, the transit country infrastructure variable inftrans $_{j t}$ for importer $j$ in year $t$ thus takes on the value of the seaport infrastructure quality of the assigned transit country in year $t$. If a country has direct access to the sea, it always takes the value 0

5 Available under: http://ec.europa.eu/transport/infrastructure/tentec/tentec-portal/map/maps. html Date of access: 18th September 2018.

6 It should be noted that the dataset does not report any maritime export flows originating from one of the five countries, but there are maritime trade flows where these countries are reported as the importing country. Therefore, it is sufficient to create only one unilateral transit country infrastructure variable for the importing countries. 
For land trade flows, on the other hand, one bilateral transit country infrastructure variable is created for each trading pair and each year. First, transit countries are assigned to each pair of trading partners by identifying the most plausible transport route between the two trading partners. For this purpose, it is assumed that transport operators always try to move their goods on the TEN$\mathrm{T}$ core corridors, which are designed to facilitate the transport of goods within Europe. Moreover, transport operators are assumed to chose the shortest route that can be taken when using mostly the TEN-T core corridor infrastructure. With these two criteria, I select the shortest possible TEN-T core corridor road or rail transport route between the two trading partners. All countries lying on this route are assigned as transit countries to the pair of trading partners. Next, the transit country infrastructure quality variable inftrans ${ }_{i j t}$ for exporter $i$ and importer $j$ in year $t$ thus takes on the average value or the minimum value of the road or railroad infrastructure qualities in year $t$ over all transit countries that were assigned to the two trading partners. If two countries share a common border, the transit variable always takes the value 0 .

As it is not clear whether waterway export flows only use inland waterways or also adjoining seas, it is subsequently impossible to approximate real routes and it is not even clear whether one bilateral or two unilateral transit infrastructure variables would be appropriate. Therefore, I completely refrain from modeling transit country infrastructure variables for this mode of transport.

Please note that the transit country infrastructure variable is only calculated for the quality indicators. The infrastructure quantity indicators observe several missing values which would render the calculation of quantitative transit country infrastructure variables impossible for many pairs of trading partners.

The transit country infrastructure variables are transformed to $\ln (1+$ inftrans $)$ before being included in the regression. This is necessary in order to include coastal countries (for sea trade) and contiguous trade partners (for road and rail trade), for which the logarithm of the transit variable would otherwise not be defined, in the regression. Subsequently, the estimated regression coefficients need to be multiplied by inftrans $/(1+$ inftrans $)$ in order to obtain the correct trade elasticities of infrastructure variables (Limao and Venables, 2001).7]

\section{Methodology}

After selecting the infrastructure and control variables, it is important to find the correct form and regression method for the model. Traditionally, a loglinearized version of the gravity equation is estimated using an ordinary least squares (OLS) regression, but Silva and Tenreyro (2006) point out that this method is flawed and produces biased estimates. Another problem that is inherent to the log-linearized OLS regression method is the handling of zero trade flows, which cannot be used in the log-linearized version, as the logarithm of zero is not defined. In order to regress datasets with zeros, it is therefore necessary either to eliminate zero trade flows and lose information from these observations, or to find another workaround. Silva and Tenreyro (2006) recommend a pseudo-maximum-likelihood (PML) estimation technique to circumvent the aforementioned problems. The advantage of PML regression methods is that they are

7 These correctional factors are as follows: 0.800 for $\ln ($ transit_rail_quality_avg); 0.764 for $\ln$ (transit_rail_quality_min); $\quad 0.811$ for $\ln$ (transit_road_quality_avg); 0.775 for $\ln ($ transit_road_quality_min); and 0.496 for $\ln ($ transit_seaport_quality_imp). 
consistent and also reasonably efficient for various heteroskedasticity patterns. Furthermore, they are easy to implement and, as the dependent variable enters the specification in levels and not in logarithms, it is possible to include zero trade flows in the regression. In particular, the Poisson pseudo-maximum-likelihood (PPML) regression method emerges as the best available estimator, because it is reliable in various situations. Silva and Tenreyro (2006) conduct a case study for different measurement errors that might be present in the data and come to the conclusion that the PPML regression method remains robust for all considered cases. This result is supported by an extensive Monte Carlo simulation analysis by Egger and Staub (2016), who find that the PPML estimator is among the best all-around estimators and works well for small or large samples, as well as for various stochastic processes. Moreover, it is noteworthy that the interpretation of PML regression results is similar to OLS, as the estimates have to be interpreted as elasticities.

Having established that PPML is the superior estimation technique, it is now possible to formulate the model:

$$
\begin{aligned}
\text { tradeflow }_{i j t}=\exp [ & a_{0}+a_{1} \ln \left(G D P_{i t}\right)+a_{2} \ln \left(G D P_{j t}\right) \\
& +a_{3} \ln \left(\text { distance }_{i j}\right)+a_{4} \ln \left(\text { inf }_{i t}\right)+a_{5} \ln \left(\text { inf }_{j t}\right) \\
& +a_{6} \ln \left(\text { GDPPC }_{i t}\right)+a_{7} \ln \left(G D P P C_{j t}\right) \\
& +a_{8} \text { contiguity }_{i j}+a_{9} \text { language }_{i j} \\
& +a_{10} \text { landlocked }_{i}+a_{11} \text { landlocked }_{j} \\
& +a_{12} \text { island }_{i}+a_{13} \text { island }_{j} \\
& +a_{14} \ln \left(\text { regulation }_{i t}\right)+a_{15} \ln \left(\text { regulation }_{j t}\right) \\
& \left.+a_{16} \ln \left(\text { customs }_{j t}\right)+a_{17} \text { EU }_{i j t}\right] \times \eta_{i j t .} .
\end{aligned}
$$

Note that variables for transit country infrastructure can additionally be included for the transport modes of road, rail, and sea. Furthermore, time-dummies are always included to account for time-specific fixed effects such as crises and for the deflation of nominal monetary values (Baldwin and Taglioni, 2006).

Arguing along the lines of Anderson and van Wincoop (2003) and directly following Baier and Bergstrand (2009) and Portugal-Perez and Wilson (2012), I include multilateral resistance terms (MRTs) for all bilateral variables. Theoretically motivated MRTs control for the fact that international trade flows are not only determined by absolute bilateral trade barriers between countries $i$ and $j$, but also by the bilateral trade barrier between country $i$ and country $j$, relative to the average trade barrier between country $i$ and the rest of the world. Thus, an inclusion of MRTs reduces omitted variable bias and consequently improves the estimation of infrastructure trade elasticities.

Yotov et al. (2016) state that gravity equations should be estimated at the level of disaggregation for which the regression estimates of the important variables are wanted. Here, these variables are infrastructure variables at the level of the transport mode. Consequently, running individual regressions for each considered mode of transport should be the best way to proceed. For the cross-mode analysis in Section III.E, however, all trade flows have to be considered simultaneously. Moreover, the basic regressions are run separately for quality and for quantity indicators, thus allowing to better differentiate quality effects from quantity effects. 
The robustness of these results again is tested in a sensitivity analysis where both quality and quantity indicators are included simultaneously.

As I use a set of panel data, the regression estimates have to be treated as shortterm effects (Egger and Pfaffermayr, 2003). Furthermore, Moulton (1990) and Egger and Tarlea (2015) have highlighted the importance of clustering standard errors when working with grouped data, in order to avoid a downward bias in the regression results. For gravity equation models, it is common practice to use robust standard errors clustered at the country-pair level (Yotov et al., 2016, Helpman et al., 2008; Cameron et al., 2011).

\section{Results}

\section{A. Infrastructure Quality Regressions}

The underlying data of this study enable a differentiation of trade effects of typical gravity variables over different transport modes. These results, as well as the effects of transport infrastructure quality variables on trade flows of the accompanying transport mode, are reported in Table 3 .

It can be seen that the negative effect of distance on international trade flows is the weakest for air trade. Also, it is plausible that a common border only has a positive effect on trade for the transport modes of road, rail, and waterway. Furthermore, the results suggest that being a landlocked country has positive effects on trade for the transport modes of road and rail, whereas being an island decreases imports of these transport modes, as well as of waterway imports. As expected, islands appear to trade more via transport modes of sea and air. The extremely positive effect of an EU membership should be viewed with caution, because of an inherent selection bias 8

When looking at the transport infrastructure quality variables, some interesting results can be observed. Neither road exports nor road imports appear to be affected by the quality of the road infrastructure. Road quality improvements can only increase trade flows via roads if the road quality of the transit country with the lowest road quality is improved. Improving the railroad infrastructure quality by $1 \%$, however, can lead to export increases of around $1.4 \%$. Moreover, both the average and the minimum railroad infrastructure quality over all transit countries en route are highly significant, and improvements in these qualities promise strong trade effects. The corrected trade elasticities are 0.886 and 0.876 , respectively 9 Sea trade appears not to be affected by seaport quality improvements. Waterway trade, on the other hand, shows very high responsiveness to port-quality improvements. The corresponding export elasticity is 3.238 and the import elasticity is 4.332 , but these estimates should be viewed with caution as there are many zero trade flows for waterway trade. Also, airport infrastructure quality has a very strong and significant influence on bilateral trade flows of the air transport mode. An improvement of the airport infrastructure quality by $1 \%$ leads to export increases of $2.662 \%$ and import increases of $1.309 \%$.

Croatia is the only country in the panel data set that has not always been a member of the EU.

Corrected trade elasticities are calculated as the product of the reported regression coefficients and the correctional factors reported in Section II.B 
TABLE 3- QUALITY Regression Results

\begin{tabular}{|c|c|c|c|c|c|c|c|}
\hline & \multicolumn{2}{|c|}{ Road } & \multicolumn{2}{|c|}{ Rail } & \multirow{2}{*}{$\begin{array}{l}\text { Sea } \\
(5)\end{array}$} & \multirow{2}{*}{$\begin{array}{c}\text { Waterway } \\
(6)\end{array}$} & \multirow{2}{*}{$\begin{array}{l}\text { Air } \\
(7)\end{array}$} \\
\hline & (1) & $(2)$ & (3) & (4) & & & \\
\hline \multicolumn{8}{|l|}{ Gravity Variables } \\
\hline $\ln ($ GDP_exp) & $\begin{array}{l}0.911^{* * *} \\
(0.069)\end{array}$ & $\begin{array}{l}0.868^{* * *} \\
(0.070)\end{array}$ & $\begin{array}{l}0.607^{* * *} \\
(0.164)\end{array}$ & $\begin{array}{l}0.547^{* * *} \\
(0.166)\end{array}$ & $\begin{array}{l}0.643^{* * *} \\
(0.104)\end{array}$ & $\begin{array}{l}0.627^{* * *} \\
(0.213)\end{array}$ & $\begin{array}{l}0.811^{* * *} \\
(0.093)\end{array}$ \\
\hline ln(GDP_imp) & $\begin{array}{l}0.854^{* * *} \\
(0.055)\end{array}$ & $\begin{array}{l}0.817^{* * * *} \\
(0.052)\end{array}$ & $\begin{array}{l}0.700^{* * *} \\
(0.132)\end{array}$ & $\begin{array}{l}0.655^{* * * *} \\
(0.133)\end{array}$ & $\begin{array}{l}0.820^{* * *} \\
(0.078)\end{array}$ & $\begin{array}{l}0.768^{* * *} \\
(0.118)\end{array}$ & $\begin{array}{l}0.693^{* * * *} \\
(0.074)\end{array}$ \\
\hline $\ln ($ distance $)$ & $\begin{array}{c}-1.226^{* * *} \\
(0.089)\end{array}$ & $\begin{array}{c}-1.190^{* * *} \\
(0.090)\end{array}$ & $\begin{array}{c}-1.115^{* * *} \\
(0.184)\end{array}$ & $\begin{array}{c}-1.003^{* * *} \\
(0.177)\end{array}$ & $\begin{array}{c}-1.033^{* * *} \\
(0.121)\end{array}$ & $\begin{array}{c}-2.096^{* * *} \\
(0.366)\end{array}$ & $\begin{array}{c}-0.612^{\text {**** }} \\
(0.189)\end{array}$ \\
\hline \multicolumn{8}{|l|}{ Infrastructure } \\
\hline $\ln ($ road_quality_exp) & $\begin{array}{c}0.251 \\
(0.198)\end{array}$ & $\begin{array}{c}0.248 \\
(0.196)\end{array}$ & & & & & \\
\hline $\ln$ (road_quality_imp) & $\begin{array}{c}0.185 \\
(0.236)\end{array}$ & $\begin{array}{c}0.189 \\
(0.230)\end{array}$ & & & & & \\
\hline $\ln$ (transit_road_quality_avg) & $\begin{array}{c}0.154 \\
(0.236)\end{array}$ & & & & & & \\
\hline ln(transit_road_quality_min) & & $\begin{array}{l}0.369^{* *} \\
(0.170)\end{array}$ & & & & & \\
\hline $\ln ($ rail_quality_exp) & & & $\begin{array}{l}1.413^{* * *} \\
(0.403)\end{array}$ & $\begin{array}{l}1.421^{* * *} \\
(0.401)\end{array}$ & & & \\
\hline ln(rail_quality_imp) & & & $\begin{array}{c}-0.434 \\
(0.475)\end{array}$ & $\begin{array}{c}-0.419 \\
(0.469)\end{array}$ & & & \\
\hline $\ln$ (transit_rail_quality_avg) & & & $\begin{array}{l}1.107^{* *} \\
(0.465)\end{array}$ & & & & \\
\hline $\ln$ (transit_rail_quality_min) & & & & $\begin{array}{l}1.147^{* * *} \\
(0.387)\end{array}$ & & & \\
\hline ln(seaport_quality_exp) & & & & & $\begin{array}{c}0.744 \\
(0.648)\end{array}$ & $\begin{array}{l}3.238^{* * *} \\
(1.163)\end{array}$ & \\
\hline ln(seaport_quality_imp) & & & & & $\begin{array}{c}1.002 \\
(0.719)\end{array}$ & $\begin{array}{l}4.332^{* * *} \\
(1.654)\end{array}$ & \\
\hline $\ln$ (transit_seaport_quality_imp) & & & & & $\begin{array}{c}-0.557 \\
(1.150)\end{array}$ & & \\
\hline $\ln$ (airport_quality_exp) & & & & & & & $\begin{array}{l}2.662^{\text {*** }} \\
(0.440)\end{array}$ \\
\hline ln(airport_quality_imp) & & & & & & & $\begin{array}{l}1.309^{* * *} \\
(0.432)\end{array}$ \\
\hline \multicolumn{8}{|l|}{ Control Variables } \\
\hline $\ln$ (GDPPC_exp) & $\begin{array}{c}-0.790^{* * *} \\
(0.167)\end{array}$ & $\begin{array}{c}-0.802^{\text {*** }} \\
(0.164)\end{array}$ & $\begin{array}{c}-1.843^{* * *} \\
(0.215)\end{array}$ & $\begin{array}{c}-1.840^{* * *} \\
(0.214)\end{array}$ & $\begin{array}{c}0.438 \\
(0.304)\end{array}$ & $\begin{array}{c}-1.815^{* * *} \\
(0.501)\end{array}$ & $\begin{array}{c}-0.145 \\
(0.171)\end{array}$ \\
\hline $\ln ($ GDPPC_imp) & $\begin{array}{c}-0.765^{* * *} \\
(0.155)\end{array}$ & $\begin{array}{c}-0.776^{* * *} \\
(0.152)\end{array}$ & $\begin{array}{c}-0.508^{* *} \\
(0.218)\end{array}$ & $\begin{array}{c}-0.503^{* *} \\
(0.219)\end{array}$ & $\begin{array}{c}-0.243 \\
(0.218)\end{array}$ & $\begin{array}{l}-1.419^{* * *} \\
(0.528)\end{array}$ & $\begin{array}{c}-0.287^{*} \\
(0.168)\end{array}$ \\
\hline contiguity & $\begin{array}{c}0.356 \\
(0.459)\end{array}$ & $\begin{array}{c}0.779^{* *} \\
(0.342)\end{array}$ & $\begin{array}{l}2.003^{* *} \\
(0.841)\end{array}$ & $\begin{array}{l}2.120^{* * *} \\
(0.700)\end{array}$ & $\begin{array}{c}-0.734^{*} \\
(0.395)\end{array}$ & $\begin{array}{l}1.020^{* *} \\
(0.509)\end{array}$ & $\begin{array}{c}0.022 \\
(0.244)\end{array}$ \\
\hline language & $\begin{array}{l}0.497^{* *} \\
(0.198)\end{array}$ & $\begin{array}{l}0.507^{* *} \\
(0.199)\end{array}$ & $\begin{array}{l}0.830^{* * * *} \\
(0.159)\end{array}$ & $\begin{array}{l}0.831^{* * *} \\
(0.159)\end{array}$ & $\begin{array}{l}0.235 \\
(0.412)\end{array}$ & $\begin{array}{l}1.329^{* * *} \\
(0.442)\end{array}$ & $\begin{array}{c}-0.479 \\
(0.302)\end{array}$ \\
\hline landlocked_exp & $\begin{array}{l}0.756^{* * *} \\
(0.138)\end{array}$ & $\begin{array}{l}0.725^{* * *} \\
(0.137)\end{array}$ & $\begin{array}{l}1.391^{* * *} \\
(0.229)\end{array}$ & $\begin{array}{l}1.324^{* * *} \\
(0.230)\end{array}$ & & $\begin{array}{c}0.970 \\
(0.708)\end{array}$ & $\begin{array}{r}-0.305^{*} \\
(0.183)\end{array}$ \\
\hline landlocked_imp & $\begin{array}{l}0.289^{* * *} \\
(0.109)\end{array}$ & $\begin{array}{c}0.274^{* *} \\
(0.108)\end{array}$ & $\begin{array}{l}0.496^{* * *} \\
(0.155)\end{array}$ & $\begin{array}{l}0.469^{* * *} \\
(0.155)\end{array}$ & $\begin{array}{c}-0.839 \\
(2.117)\end{array}$ & $\begin{array}{c}0.324 \\
(0.709)\end{array}$ & $\begin{array}{c}0.024 \\
(0.239)\end{array}$ \\
\hline island_exp & $\begin{array}{c}-0.359 \\
(0.535)\end{array}$ & $\begin{array}{c}-0.381 \\
(0.536)\end{array}$ & & & $\begin{array}{c}-0.366 \\
(0.264)\end{array}$ & & $\begin{array}{l}2.019^{* * * *} \\
(0.190)\end{array}$ \\
\hline island_imp & $\begin{array}{c}-0.654^{* * *} \\
(0.139)\end{array}$ & $\begin{array}{c}-0.701^{* * *} \\
(0.135)\end{array}$ & $\begin{array}{c}-1.222^{* * *} \\
(0.365)\end{array}$ & $\begin{array}{c}-1.212^{* * *} \\
(0.356)\end{array}$ & $\begin{array}{l}0.390^{* *} \\
(0.173)\end{array}$ & $\begin{array}{c}-1.670^{* *} \\
(0.737)\end{array}$ & $\begin{array}{c}0.282^{*} \\
(0.171)\end{array}$ \\
\hline $\ln ($ regulation_exp) & $\begin{array}{l}1.054^{* * *} \\
(0.196)\end{array}$ & $\begin{array}{l}1.118^{* * * *} \\
(0.185)\end{array}$ & $\begin{array}{l}1.140^{* * *} \\
(0.384)\end{array}$ & $\begin{array}{l}1.160^{* * * *} \\
(0.373)\end{array}$ & $\begin{array}{l}2.180^{* * *} \\
(0.346)\end{array}$ & $\begin{array}{c}1.317 \\
(0.820)\end{array}$ & $\begin{array}{l}0.663^{\text {**** }} \\
(0.221)\end{array}$ \\
\hline ln(regulation_imp) & $\begin{array}{l}0.478^{* *} \\
(0.227)\end{array}$ & $\begin{array}{l}0.512^{* *} \\
(0.225)\end{array}$ & $\begin{array}{c}0.217 \\
(0.308)\end{array}$ & $\begin{array}{l}0.247 \\
(0.308)\end{array}$ & $\begin{array}{l}0.647 \\
(0.459)\end{array}$ & $\begin{array}{l}3.144^{\text {*** }} \\
(0.915)\end{array}$ & $\begin{array}{c}-0.570 \\
(0.361)\end{array}$ \\
\hline $\ln$ (customs_imp) & $\begin{array}{c}0.137 \\
(0.459)\end{array}$ & $\begin{array}{c}0.139 \\
(0.460)\end{array}$ & $\begin{array}{c}0.302 \\
(0.747)\end{array}$ & $\begin{array}{c}0.278 \\
(0.743)\end{array}$ & $\begin{array}{c}0.521 \\
(1.080)\end{array}$ & $\begin{array}{c}-1.533 \\
(2.138)\end{array}$ & $\begin{array}{c}0.042 \\
(0.798)\end{array}$ \\
\hline $\mathrm{EU}$ & $\begin{array}{l}8.135^{* * *} \\
(0.697)\end{array}$ & $\begin{array}{l}7.660^{* * * *} \\
(0.723)\end{array}$ & $\begin{array}{l}5.601^{* * *} \\
(1.248)\end{array}$ & $\begin{array}{l}4.744^{* * * *} \\
(1.262)\end{array}$ & $\begin{array}{l}8.091^{* * *} \\
(0.845)\end{array}$ & $\begin{array}{l}13.403^{* * *} \\
(2.661)\end{array}$ & $\begin{array}{l}3.919^{* * * *} \\
(1.464)\end{array}$ \\
\hline Constant & $\begin{array}{l}11.573^{* * *} \\
(2.193)\end{array}$ & $\begin{array}{l}12.530^{* * *} \\
(2.109)\end{array}$ & $\begin{array}{l}20.612^{* * * *} \\
(4.495)\end{array}$ & $\begin{array}{l}21.905^{* * * *} \\
(4.560)\end{array}$ & $\begin{array}{l}-8.334^{* * *} \\
(2.482)\end{array}$ & $\begin{array}{l}15.042^{\text {**** }} \\
(5.838)\end{array}$ & $\begin{array}{c}-4.463^{*} \\
(2.319) \\
\end{array}$ \\
\hline Observations & 4320 & 4320 & 3400 & 3400 & 3456 & 3672 & 4320 \\
\hline$R^{2}$ & 0.910 & 0.911 & 0.799 & 0.801 & 0.726 & 0.832 & 0.841 \\
\hline Year Fixed Effects & Yes & Yes & Yes & Yes & Yes & Yes & Yes \\
\hline Multilateral Resistance & Yes & Yes & Yes & Yes & Yes & Yes & Yes \\
\hline
\end{tabular}

$* \mathrm{p}<0.1, * * \mathrm{p}<0.05, * * * \mathrm{p}<0.01$. Standard errors in parentheses.

Note: The dependent variable is tradeflow. Standard errors are robust and clustered at the country-pair level. Regression coefficients for some control variables are not reported. The corresponding variables were originally included in the regression specification, but Stata ${ }^{\circledR}$ deletes these variables in order to ensure that the PPML regressor converges and that the estimates exist. Furthermore, observations are automatically excluded from the regression if one of the variables is reported as missing. Note that the regression coefficients for transit country infrastructure variables have to be corrected with the correctional factors reported in Section III.B. Source: Own calculation. 


\section{B. Infrastructure Quantity Regressions}

To estimate trade effects of infrastructure quantity improvements, the same method as for the quality analysis is used. The results can be found in Table 4. In contrast to road quality improvements, an increase in the road density significantly affects trade flows. The export elasticity with respect to road density increases is 0.287 and the corresponding import elasticity is 0.110 . The rail density, on the other hand, has no effect on neither rail exports nor rail imports. Sea trade is influenced by changes in the LSCI. As the LSCI is a composite index of quantitative indicators, the interpretation is not straightforward. Nevertheless, the results suggest that an increase in the quantitative capabilities of a country's seaports will counter-intuitively lower its exports, and at the same time, increase imports by roughly the same amount. For both waterway and air trade, the infrastructure quality appears to have a larger effect on trade flows than the infrastructure quantity. For waterway trade, a $1 \%$ increase in the waterway density of a country can raise imports by $0.656 \%$. Waterway exports are not affected by improvements in waterway density. Increasing the airport density by $1 \%$ can lead to a $0.204 \%$ increase in air imports. Such an improvement has, however, no effect on air exports of the respective country.

\section{Sensitivity Analyses}

In Table 5, the regression coefficients of relevant infrastructure variables are reported for various sensitivity analyses. The upper part of the table refers to infrastructure quality regressions and the lower part to infrastructure quantity regressions. In the first column, the results of the base specification are repeated. To test the robustness of results, the original regression model can be augmented by including additional control variables that might exert influence on the trade flows of a country. Thus, I include the geographical size of a country (Source: World Development Indicators (WDI)). Also, as the composition and the organization of economic activities can influence a country's ability and propensity to trade, additional indicators of public sector performance, overall competition from both the domestic and the foreign market, the enforcement of property rights, broadness of the country's presence in an average value chain and the quality of the customs environment of the exporter are included in the regression. As social aspects might also be important, indicators of ethical standards and corruption as well as on how secure a country is, are now considered. To incorporate the technological state of a country, the quality of the electricity and telecommunication infrastructure and the dissemination of ICT usage (Source: GCR) are accounted for. Moreover, bilateral variables on whether two countries have a similar legal system (Source: JuriGlobe 10 ) and on whether countries have had a common colonizer in the past (Source: Mayer and Zignago (2011)), are included to account for bilateral idiosyncrasies that could influence the relationship between two countries and subsequently their inclination to trade with each other. The sensitivity analysis shows that the results of infrastructure quality variables are mostly robust to the addition of more control variables. However, road exports and sea imports are now positively affected by quality improvements of the corresponding infrastructure type. Also, the average road quality over all of access: 7 th June 2017. Note that this variable is not time-specific, but constant over time. 
TABLE 4-QUANTITy REgRession Results

\begin{tabular}{|c|c|c|c|c|c|}
\hline & Road & Rail & Sea & Waterway & Air \\
\hline & (1) & $(2)$ & $(3)$ & (4) & (5) \\
\hline \multicolumn{6}{|l|}{ Gravity Variables } \\
\hline $\ln ($ GDP_exp) & $\begin{array}{l}0.975^{* * *} \\
(0.068)\end{array}$ & $\begin{array}{l}0.882^{* * *} \\
(0.217)\end{array}$ & $\begin{array}{l}0.661^{* * *} \\
(0.098)\end{array}$ & $\begin{array}{c}-0.376 \\
(0.257)\end{array}$ & $\begin{array}{l}0.886^{* * * *} \\
(0.140)\end{array}$ \\
\hline $\ln \left(\mathrm{GDP} \_i m p\right)$ & $\begin{array}{l}0.834^{* * *} \\
(0.045)\end{array}$ & $\begin{array}{l}0.720^{* * *} \\
(0.145)\end{array}$ & $\begin{array}{l}0.673^{* * *} \\
(0.109)\end{array}$ & $\begin{array}{r}-0.652^{*} \\
(0.387)\end{array}$ & $\begin{array}{l}0.776^{* * * *} \\
(0.084)\end{array}$ \\
\hline $\ln ($ distance $)$ & $\begin{array}{c}-1.017^{* * * *} \\
(0.082)\end{array}$ & $\begin{array}{c}-1.327^{* * *} \\
(0.331)\end{array}$ & $\begin{array}{c}-1.123^{* * *} \\
(0.111)\end{array}$ & $\begin{array}{c}-1.070^{* * *} \\
(0.312)\end{array}$ & $\begin{array}{c}-0.640^{* * * *} \\
(0.186)\end{array}$ \\
\hline \multicolumn{6}{|l|}{ Infrastructure } \\
\hline ln(road_quantity_exp) & $\begin{array}{l}0.287^{* * *} \\
(0.074)\end{array}$ & & & & \\
\hline ln(road_quantity_imp) & $\begin{array}{c}0.110^{*} \\
(0.061)\end{array}$ & & & & \\
\hline ln(rail_quantity_exp) & & $\begin{array}{c}-0.241 \\
(0.172)\end{array}$ & & & \\
\hline ln(rail_quantity_imp) & & $\begin{array}{c}-0.038 \\
(0.170)\end{array}$ & & & \\
\hline ln(seaport_quantity_exp) & & & $\begin{array}{c}-0.256^{* *} \\
(0.114)\end{array}$ & & \\
\hline $\ln$ (seaport_quantity_imp) & & & $\begin{array}{c}0.268^{*} \\
(0.141)\end{array}$ & & \\
\hline ln(waterway_quantity_exp) & & & & $\begin{array}{c}0.715 \\
(0.724)\end{array}$ & \\
\hline $\ln$ (waterway_quantity_imp) & & & & $\begin{array}{l}0.656^{* * *} \\
(0.165)\end{array}$ & \\
\hline $\ln$ (airport_quantity_exp) & & & & & $\begin{array}{c}0.130 \\
(0.104)\end{array}$ \\
\hline $\ln$ (airport_quantity_imp) & & & & & $\begin{array}{c}0.204^{*} \\
(0.124)\end{array}$ \\
\hline \multicolumn{6}{|l|}{ Control Variables } \\
\hline $\ln ($ GDPPC_exp) & $\begin{array}{c}-1.446^{* * *} \\
(0.121)\end{array}$ & $\begin{array}{c}-1.581^{* * *} \\
(0.264)\end{array}$ & $\begin{array}{l}0.730 * * * \\
(0.150)\end{array}$ & $\begin{array}{c}-1.541^{* *} \\
(0.690)\end{array}$ & $\begin{array}{c}0.156 \\
(0.197)\end{array}$ \\
\hline $\ln ($ GDPPC_imp) & $\begin{array}{c}-0.889^{* * *} \\
(0.139)\end{array}$ & $\begin{array}{c}-0.400 \\
(0.317)\end{array}$ & $\begin{array}{c}-0.085 \\
(0.181)\end{array}$ & $\begin{array}{r}2.119^{*} \\
(1.129)\end{array}$ & $\begin{array}{r}-0.350 \\
(0.216)\end{array}$ \\
\hline contiguity & $\begin{array}{c}0.213^{*} \\
(0.109)\end{array}$ & $\begin{array}{c}0.049 \\
(0.281)\end{array}$ & $\begin{array}{c}-0.795^{*} \\
(0.412)\end{array}$ & $\begin{array}{l}1.793^{* * *} \\
(0.520)\end{array}$ & $\begin{array}{c}0.065 \\
(0.262)\end{array}$ \\
\hline language & $\begin{array}{l}0.542^{* * * *} \\
(0.169)\end{array}$ & $\begin{array}{c}-0.037 \\
(0.534)\end{array}$ & $\begin{array}{c}0.265 \\
(0.434)\end{array}$ & $\begin{array}{c}-2.086^{* *} \\
(0.921)\end{array}$ & $\begin{array}{c}-0.551^{*} \\
(0.333)\end{array}$ \\
\hline landlocked_exp & $\begin{array}{l}1.046^{* * *} \\
(0.147)\end{array}$ & $\begin{array}{l}1.988^{* * *} \\
(0.380)\end{array}$ & & $\begin{array}{l}1.389^{* * *} \\
(0.537)\end{array}$ & $\begin{array}{c}-0.480^{* *} \\
(0.208)\end{array}$ \\
\hline landlocked_imp & $\begin{array}{l}0.349^{* * *} \\
(0.099)\end{array}$ & $\begin{array}{c}0.311 \\
(0.313)\end{array}$ & & $\begin{array}{c}0.399 \\
(0.574)\end{array}$ & $\begin{array}{c}0.029 \\
(0.236)\end{array}$ \\
\hline island_exp & $\begin{array}{c}-0.014 \\
(0.233)\end{array}$ & & $\begin{array}{c}-0.753^{* * *} \\
(0.184)\end{array}$ & & $\begin{array}{l}1.689^{* * *} \\
(0.199)\end{array}$ \\
\hline island_imp & $\begin{array}{c}-0.622^{* * *} \\
(0.107)\end{array}$ & $\begin{array}{c}-0.847^{*} \\
(0.433)\end{array}$ & $\begin{array}{l}0.357^{* *} \\
(0.161)\end{array}$ & $\begin{array}{r}-0.840 \\
(0.564)\end{array}$ & $\begin{array}{c}0.079 \\
(0.202)\end{array}$ \\
\hline $\ln ($ regulation_exp) & $\begin{array}{l}1.436^{* * *} \\
(0.157)\end{array}$ & $\begin{array}{l}1.421^{* * *} \\
(0.521)\end{array}$ & $\begin{array}{l}1.725^{* * *} \\
(0.407)\end{array}$ & $\begin{array}{l}3.045^{* * *} \\
(0.870)\end{array}$ & $\begin{array}{l}1.540^{* * * *} \\
(0.318)\end{array}$ \\
\hline $\ln ($ regulation_imp $)$ & $\begin{array}{l}0.668^{* * *} \\
(0.203)\end{array}$ & $\begin{array}{c}0.316 \\
(0.525)\end{array}$ & $\begin{array}{c}0.705 \\
(0.474)\end{array}$ & $\begin{array}{l}2.717^{* * *} \\
(0.808)\end{array}$ & $\begin{array}{c}-0.484 \\
(0.436)\end{array}$ \\
\hline $\ln ($ customs_imp) & $\begin{array}{c}0.415 \\
(0.444)\end{array}$ & $\begin{array}{c}-0.383 \\
(0.957)\end{array}$ & $\begin{array}{l}1.190 \\
(0.866)\end{array}$ & $\begin{array}{c}-7.081^{* * *} \\
(2.218)\end{array}$ & $\begin{array}{c}1.088 \\
(0.808)\end{array}$ \\
\hline $\mathrm{EU}$ & $\begin{array}{l}6.553^{* * *} \\
(0.629)\end{array}$ & $\begin{array}{l}8.054^{* * *} \\
(2.335)\end{array}$ & $\begin{array}{l}8.590^{* * *} \\
(0.801)\end{array}$ & $\begin{array}{c}4.555^{* *} \\
(2.105)\end{array}$ & $\begin{array}{l}4.243^{* * * *} \\
(1.486)\end{array}$ \\
\hline Constant & $\begin{array}{l}19.990^{* * *} \\
(1.840)\end{array}$ & $\begin{array}{l}15.328^{* * *} \\
(3.798)\end{array}$ & $\begin{array}{c}-9.011^{* * *} \\
(2.276)\end{array}$ & $\begin{array}{c}33.348^{* *} \\
(13.302)\end{array}$ & $\begin{array}{c}-1.592 \\
(3.066)\end{array}$ \\
\hline Observations & 2450 & 2076 & 2816 & 1035 & 3780 \\
\hline$R^{2}$ & 0.941 & 0.686 & 0.737 & 0.947 & 0.811 \\
\hline Year Fixed Effects & Yes & Yes & Yes & Yes & Yes \\
\hline Multilateral Resistance & Yes & Yes & Yes & Yes & Yes \\
\hline
\end{tabular}

$* \mathrm{p}<0.1, * * \mathrm{p}<0.05, * * * \mathrm{p}<0.01$. Standard errors in parentheses.

Note: The dependent variable is tradeflow. Standard errors are robust and clustered at the countrypair level. Regression coefficients for some control variables are not reported. The corresponding variables were originally included in the regression specification, but Stata ${ }^{\circledR}$ deletes these variables in order to ensure that the PPML regressor converges and that the estimates exist. Furthermore, observations are automatically excluded from the regression if one of the variables is reported as missing. Source: Own calculation. 
Table 5 - Sensitivity Analyses Overview

\begin{tabular}{|c|c|c|c|c|c|}
\hline & \multicolumn{5}{|c|}{ Quality Regressions } \\
\hline & $\begin{array}{c}\text { Base } \\
\text { Specification }\end{array}$ & $\begin{array}{l}\text { Additional } \\
\text { Controls }\end{array}$ & $\begin{array}{c}\text { Lagged } \\
\text { Infrastructure }\end{array}$ & $\begin{array}{l}\text { Country } \\
\text { FE }\end{array}$ & $\begin{array}{l}\text { Pair } \\
\text { FE }\end{array}$ \\
\hline \multicolumn{6}{|l|}{ Road Transport (Transit Avg.) } \\
\hline $\begin{array}{l}\ln (\text { road_quality_exp) } \\
\ln (\text { road_quality_imp) } \\
\ln (\text { transit_road_quality_avg) }\end{array}$ & $\begin{array}{l}0.251 \\
0.185 \\
0.154\end{array}$ & $\begin{array}{l}1.174^{* * *} \\
0.301 \\
0.534^{* * *}\end{array}$ & $\begin{array}{l}0.247 \\
0.155 \\
0.433^{*}\end{array}$ & $\begin{array}{l}0.078 \\
0.258^{* * *} \\
0.927^{* * *}\end{array}$ & $\begin{array}{r}0.097^{*} \\
0.227^{* * *} \\
-0.511^{* * *}\end{array}$ \\
\hline $\begin{array}{l}\text { Road Transport (Transit Min.) } \\
\ln (\text { road_quality_exp) } \\
\ln (\text { road_quality_imp) } \\
\text { ln(transit_road_quality_min) }\end{array}$ & $\begin{array}{l}0.248 \\
0.189 \\
0.369^{* *}\end{array}$ & $\begin{array}{l}1.160^{* * *} \\
0.282 \\
0.474^{* * *}\end{array}$ & $\begin{array}{l}0.233 \\
0.136 \\
0.546^{* * *}\end{array}$ & $\begin{array}{l}0.090 \\
0.258^{* * *} \\
0.829^{* * *}\end{array}$ & $\begin{array}{l}0.098^{*} \\
0.222^{* * *} \\
-0.183\end{array}$ \\
\hline $\begin{array}{l}\text { Rail Transport (Transit Avg.) } \\
\ln (\text { rail_quality_exp) } \\
\ln (\text { rail_quality_imp) } \\
\text { ln(transit_rail_quality_avg) }\end{array}$ & $\begin{array}{l}1.413^{* * *} \\
-0.434 \\
1.107^{* *}\end{array}$ & $\begin{aligned} & 2.795^{* * *} \\
- & 0.375 \\
& 1.138^{* *}\end{aligned}$ & $\begin{array}{l}1.496^{* * *} \\
-0.086 \\
1.338^{* * *}\end{array}$ & $\begin{array}{r}-0.559 \\
-0.934^{* * *} \\
2.178^{* * *}\end{array}$ & $\begin{array}{l}-0.657^{* *} \\
-0.934^{* * *} \\
-1.858\end{array}$ \\
\hline $\begin{array}{l}\text { Rail Transport (Transit Min.) } \\
\ln (\text { rail_quality_exp) } \\
\ln (\text { rail_quality_imp) } \\
\text { ln(transit_rail_quality_min) }\end{array}$ & $\begin{aligned} & 1.421^{* * * *} \\
- & 0.419 \\
& 1.147^{* * *}\end{aligned}$ & $\begin{array}{l}2.802^{* * *} \\
-0.358 \\
1.015^{* * *}\end{array}$ & $\begin{array}{l}1.520^{* * *} \\
-0.079 \\
1.326^{* * *}\end{array}$ & $\begin{array}{r}-0.561 \\
-0.945^{* * *} \\
1.866^{* * *}\end{array}$ & $\begin{array}{l}-0.665^{* *} \\
-0.953^{* * *} \\
-0.989\end{array}$ \\
\hline $\begin{array}{l}\text { Sea Transport } \\
\ln \text { (seaport_quality_exp) } \\
\ln (\text { seaport_quality_imp) } \\
\ln (\text { transit_seaport_quality_imp) }\end{array}$ & $\begin{array}{r}0.744 \\
1.002 \\
-0.557\end{array}$ & $\begin{aligned}- & 0.047 \\
& 1.265^{*} \\
- & 0.977\end{aligned}$ & $\begin{aligned} & 1.080 \\
& 1.339^{* *} \\
&-0.567\end{aligned}$ & $\begin{array}{c}-0.901^{* *} \\
0.168 \\
0.014\end{array}$ & $\begin{array}{c}-0.827^{* *} \\
0.187 \\
0.352\end{array}$ \\
\hline $\begin{array}{l}\text { Waterway Transport } \\
\ln \text { (seaport_quality_exp) } \\
\ln \text { (seaport_quality_imp) }\end{array}$ & $\begin{array}{l}3.238^{* * *} \\
4.332^{* * *}\end{array}$ & $\begin{array}{l}6.943^{* * *} \\
4.163^{* * *}\end{array}$ & $\begin{array}{l}3.408^{* * *} \\
2.672\end{array}$ & $\begin{array}{r}0.431 \\
-0.111\end{array}$ & $\begin{array}{r}0.169 \\
-0.365\end{array}$ \\
\hline $\begin{array}{l}\text { Air Transport } \\
\qquad \ln \text { (airport_quality_exp) } \\
\ln \text { (airport_quality_imp) }\end{array}$ & $\begin{array}{l}2.662^{* * *} \\
1.309^{* * *}\end{array}$ & $\begin{array}{l}2.139^{* * * *} \\
1.356^{* * *}\end{array}$ & $\begin{array}{l}2.313^{* * *} \\
1.300^{* * *}\end{array}$ & $\begin{array}{l}0.344 \\
0.624\end{array}$ & $\begin{array}{r}-0.050 \\
0.476 \\
\end{array}$ \\
\hline \multirow{2}{*}{$\ln$ (airport_quality_imp) } & \multicolumn{5}{|c|}{ Quantity Regressions } \\
\hline & $\begin{array}{c}\text { Base } \\
\text { Specification }\end{array}$ & $\begin{array}{c}\text { Additional } \\
\text { Controls } \\
\end{array}$ & $\begin{array}{c}\text { Lagged } \\
\text { Infrastructure }\end{array}$ & $\begin{array}{l}\text { Country } \\
\text { FE }\end{array}$ & $\begin{array}{c}\text { Pair } \\
\text { FE }\end{array}$ \\
\hline \multicolumn{6}{|l|}{ Road Transport (Transit Avg.) } \\
\hline $\begin{array}{l}\ln (\text { road_quantity_exp) } \\
\ln (\text { road_quantity_imp) }\end{array}$ & $\begin{array}{l}0.287^{* * *} \\
0.110^{*}\end{array}$ & $\begin{array}{l}0.407^{* * *} \\
0.166^{* * *}\end{array}$ & $\begin{array}{l}0.249^{* * *} \\
0.083\end{array}$ & $\begin{array}{l}0.013 \\
0.191^{* * *}\end{array}$ & $\begin{array}{r}-0.037 \\
0.077\end{array}$ \\
\hline $\begin{array}{l}\text { Rail Transport (Transit Avg.) } \\
\ln (\text { rail_quantity_exp) } \\
\ln (\text { rail_quantity_imp) }\end{array}$ & $\begin{array}{l}-0.241 \\
-0.038\end{array}$ & $\begin{array}{l}-1.210^{* * *} \\
-0.004\end{array}$ & $\begin{array}{l}-0.315^{*} \\
-0.099\end{array}$ & $\begin{array}{l}0.926^{* *} \\
0.032\end{array}$ & $\begin{array}{l}0.767^{* * *} \\
0.097\end{array}$ \\
\hline $\begin{array}{l}\text { Sea Transport } \\
\ln (\text { seaport_quantity_exp) } \\
\ln (\text { seaport_quantity_imp) }\end{array}$ & $\begin{array}{c}-0.256^{* *} \\
0.268^{*}\end{array}$ & $\begin{array}{l}-0.095 \\
0.517^{* * *}\end{array}$ & $\begin{array}{r}-0.282^{* *} \\
0.279^{* *}\end{array}$ & $\begin{array}{l}-0.058 \\
-0.051\end{array}$ & $\begin{array}{r}-0.016 \\
0.050\end{array}$ \\
\hline $\begin{array}{l}\text { Waterway Transport } \\
\ln \text { (waterway_quantity_exp) } \\
\ln \text { (waterway_quantity_imp) }\end{array}$ & $\begin{array}{l}0.715 \\
0.656^{* * *}\end{array}$ & $\begin{array}{l}1.376^{* * *} \\
0.042\end{array}$ & $\begin{array}{l}0.545 \\
0.581^{* * *}\end{array}$ & $\begin{array}{l}-2.241 \\
-1.029\end{array}$ & $\begin{array}{r}-15.956 \\
-0.157\end{array}$ \\
\hline $\begin{array}{l}\text { Air Transport } \\
\qquad \begin{array}{l}\ln (\text { airport_quantity_exp) } \\
\ln (\text { airport_quantity_imp) }\end{array}\end{array}$ & $\begin{array}{l}0.130 \\
0.204^{*}\end{array}$ & $\begin{array}{l}-0.032 \\
-0.004\end{array}$ & $\begin{array}{l}0.168 \\
0.299^{* *}\end{array}$ & $\begin{array}{c}-0.363^{* *} \\
0.047\end{array}$ & $\begin{array}{c}-0.283^{*} \\
0.042 \\
\end{array}$ \\
\hline $\begin{array}{l}\text { Year Fixed Effects } \\
\text { Multilateral Resistance } \\
\text { Lagged Infrastructure Variables } \\
\text { Country Specific Fixed Effects } \\
\text { Country Pair Fixed Effects }\end{array}$ & $\begin{array}{l}\text { Yes } \\
\text { Yes } \\
\text { No } \\
\text { No } \\
\text { No }\end{array}$ & $\begin{array}{l}\text { Yes } \\
\text { Yes } \\
\text { No } \\
\text { No } \\
\text { No }\end{array}$ & $\begin{array}{l}\text { Yes } \\
\text { Yes } \\
\text { Yes } \\
\text { No } \\
\text { No }\end{array}$ & $\begin{array}{l}\text { Yes } \\
\text { Yes } \\
\text { No } \\
\text { Yes } \\
\text { No }\end{array}$ & $\begin{array}{l}\text { Yes } \\
\text { Yes } \\
\text { No } \\
\text { No } \\
\text { Yes }\end{array}$ \\
\hline
\end{tabular}

$* \mathrm{p}<0.1,{ }^{* *} \mathrm{p}<0.05,{ }^{* * *} \mathrm{p}<0.01$. Standard errors in parentheses.

Note: This table serves as an overview of the coefficients that are relevant for the infrastructure analysis. Complete regression tables are available upon request. The dependent variable is tradeflow. Standard errors are robust and clustered at the country pair level. The infrastructure variables in the "Lagged Infrastructure" column are lagged by three years.

Source: Own calculation. 
transit countries en route appears to have a positive impact on road trade flows. When looking at the quantity regressions, the positive effects of road density improvements can be confirmed. The railroad density of a country appears to negatively affect rail exports. For sea trade, only the positive import elasticity can be confirmed and, for waterway trade, there is no longer a positive effect on waterway imports. Now, waterway exports are positively affected. The airport density appears to neither affect exports nor imports via air.

One additional aspect that arises when estimating the effects of infrastructure on trade is the problem of endogeneity caused by reverse causality. Although Francois and Manchin (2013) state that it is more likely that better infrastructure quality increases bilateral trade flows and not the other way round, it is nevertheless necessary to test the data for reverse causality. Therefore, I use infrastructure variables that are lagged by three years in another sensitivity analysis ${ }^{11}$ This procedure reduces the bias from reverse causality, as it reduces possible backwards linkages that might run from trade flows to infrastructure quality (Francois and Manchin, 2013, Bougheas et al., 1999). The results are reported in the third column of Table 5 and show that endogeneity does not seem to be a big problem for both the quality and the quantity regressions, because most of the results are similarly significant as in the base specification. Only the qualitative waterway import elasticity and the quantitative road import elasticity become insignificant.

Furthermore, the strict exogeneity test by Wooldridge (2010, p. 325) was conducted. The null hypothesis that infrastructure is strictly exogenous to trade flows can only be rejected for the quality of the railroad network. Except for railroad quality, the null hypothesis of strict exogeneity cannot be rejected at the $5 \%$ level for all other quality and quantity indicators, thus mitigating endogeneity concerns.

Besides the control variable approach used in the basic regression specification, fixed effects can be included in the regression model, in order to account for unobserved factors. Head and Mayer (2014) argue that using fixed effects for the exporting country and for the importing country is common practice and that these fixed effects can account for unobserved characteristics of the exporting and the importing country that are constant over time. Egger and Pfaffermayr (2003) and Cheng and Wall (2005) argue that the fixed effects regression model should include bilateral country pair fixed effects. Consequently, I choose to apply the fixed effects regression model with country-specific and time fixed effects, as well as a variant with country-pair specific and time fixed effects. Although fixed effects regressions have certain desirable properties, the estimated coefficients for the infrastructure variables of this analysis could be distorted and misleading, if the infrastructure variables did not vary much over time (Portugal-Perez and Wilson, 2012). Indeed, there are several countries for which infrastructure variables do not change at all or only very little over time, as is also indicated Table 2. As it turns out, the results of the fixed effects regressions are rather inconclusive and should thus be viewed with caution.

In addition to the sensitivity analyses presented in Table 5, another sensitivity analysis is conducted to test whether certain countries or years distort the outcomes of the quality and quantity regressions. For this, different subsamples are

11 The fact that three of the eight years of the sample can thus no longer be used in the regression should not cause a significant problem, because the results are generally robust to dropping one or more years from the sample, which is also shown in this sensitivity analysis. 
constructed as follows: dropping each country separately from the original sample; dropping all landlocked countries; dropping all islands; dropping each year separately; dropping a combination of different years. The main results can be confirmed for most of the subsamples that were used. One interesting change, however, is that the quality of seaport infrastructure now positively affects sea trade flows when dropping Germany or Belgium from the original sample. Further, airport infrastructure no longer affects air imports when dropping all islands from the sample. Dropping one or more years from the sample does not change results significantly. It is noteworthy that dropping the years that are closest to the great recession, that is 2010 to 2012 , does not change results significantly, thus implying that the results are not affected by unusual expenditure regimes that were caused by the crisis.

\section{Regression Model with Quality and Quantity Indicators}

In an additional sensitivity analysis, both the qualitative and the quantitative infrastructure indicators are included simultaneously in the base specification regression model. The regression coefficients of the infrastructure variables for the transport modes of road, rail, sea, and air can be seen in Table 6. Trade via waterways is excluded from this analysis due to its aforementioned status as a special case that needs to be viewed with caution.

For trade on roads, it can be confirmed that the quality of roads does neither

TABle 6-Regression Model for Simultaneous Inclusion of Quality and Quantity Indicators

\begin{tabular}{lcccc}
\hline & $\begin{array}{c}\text { Road } \\
(1)\end{array}$ & $\begin{array}{c}\text { Rail } \\
(2)\end{array}$ & $\begin{array}{c}\text { Sea } \\
(3)\end{array}$ & $\begin{array}{c}\text { Air } \\
(4)\end{array}$ \\
\hline $\ln ($ inf_quality_exp) & -0.131 & $1.298^{* *}$ & $1.604^{* *}$ & $2.754^{* * *}$ \\
& $(0.205)$ & $(0.516)$ & $(0.652)$ & $(0.414)$ \\
$\ln$ (inf_quality_imp) & 0.037 & -0.383 & 0.376 & $1.272^{* * *}$ \\
& $(0.234)$ & $(0.565)$ & $(0.792)$ & $(0.431)$ \\
$\ln ($ inf_quantity_exp) & $0.323^{* * *}$ & 0.002 & $-0.405^{* * *}$ & -0.093 \\
& $(0.092)$ & $(0.217)$ & $(0.111)$ & $(0.073)$ \\
$\ln ($ inf_quantity_imp) & $0.107^{*}$ & -0.083 & 0.236 & 0.047 \\
& $(0.063)$ & $(0.132)$ & $(0.152)$ & $(0.116)$ \\
\hline Observations & 2450 & 2076 & 2816 & 3780 \\
$R^{2}$ & 0.941 & 0.707 & 0.737 & 0.841 \\
Gravity Variables & Yes & Yes & Yes & Yes \\
Control Variables & Yes & Yes & Yes & Yes \\
Year Fixed Effects & Yes & Yes & Yes & Yes \\
Multilateral Resistance & Yes & Yes & Yes & Yes \\
\hline
\end{tabular}

${ }^{*} \mathrm{p}<0.1,{ }^{* *} \mathrm{p}<0.05,{ }^{* * *} \mathrm{p}<0.01$. Standard errors in parentheses.

Note: This table serves as an overview of the coefficients that are relevant for the infrastructure analysis. Complete regression tables are available upon request. The dependent variable is tradeflow. The independent variables are placeholders for the corresponding infrastructure types. Thus, the regression coefficients in Column 1 refer to road infrastructure, in Column 2 to rail infrastructure, in Column 3 to port infrastructure, and in Column 4 to airport infrastructure. Standard errors are robust and clustered at the country pair level.

Source: Own calculation. 
affect road exports nor road imports, but both exports and imports are significantly affected by improvements in the road density (Column 1). Furthermore, the positive export elasticity with respect to qualitative railroad infrastructure improvements can be confirmed. The density of the railroad network, however, has no effect on trade via railroads (Column 2). While sea exports are positively affected by seaport quality improvements, they seem to be negatively affected by seaport quantity improvements (Column 3). These results appear rather inconclusive and should thus be viewed with caution. For air trade, both exports and imports are positively affected by the quality of a country's airport infrastructure, but they do not respond to changes in the airport density of a country (Column $4)$.

In conclusion, the regression analyses that feature both the qualitative and the quantitative infrastructure indicators can confirm the main insights of the basic regression setups.

\section{E. Cross-Mode Analysis}

Until now, the four different transport modes road, rail, sea, and air were considered separately. Thus, the previously outlined trade effects always indicate the impact that one specific transport infrastructure type has on trade flows of the corresponding transport mode. However, it might be reasonable to assume that trade flows of one specific transport mode might be affected not only by the corresponding transport infrastructure type, but also by the other types of transport infrastructure. For example, trade via air might not only be affected by the airport infrastructure, but also by road, railroad, and seaport infrastructures as they could have complementary or competitive relationships with the airport infrastructure.

In order to shed more light on the interdependencies between different infrastructure types and trade flows of different transport modes, a novel cross-mode analysis is conducted. In this cross-mode analysis, trade flows of the transport modes road, rail, sea, and air are considered simultaneously in the regression setup ${ }^{12}$ To take into account that infrastructure indicators might have different effects for different transport modes, new infrastructure variables are created. Accordingly, the effect of each of the four infrastructure types on each of the four transport modes can be isolated and captured separately. These $4 \times 4=16$ variables are listed in Table 7. The four variables on the main diagonal capture the effect of one infrastructure type on tradeflows of the corresponding transport mode (e.g. airport_on_air). The remaining variables capture the possible cross effects of one infrastructure type on trade flows of transport modes that are different from the corresponding transport mode (e.g. road_on_air). All these variables are calculated according to the following procedure:

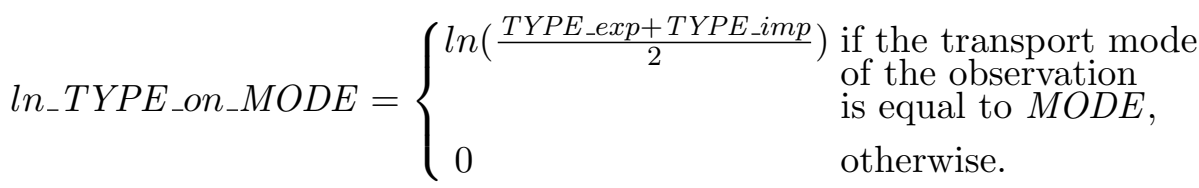
and the large number of zero trade flows. Therefore, there are 4,320 observations for each of the transport modes road, rail, sea, and air. This amounts to 17,280 observations that are considered simultaneously in this analysis. 
Here, the term TYPE can be replaced by the different infrastructure types road, rail, seaport, and airport, and the term MODE can be replaced by the different transport modes road, rail, sea, and air in order to obtain the 16 variables outlined in Table 7 .

This implies that for the transport mode of air, the relevant infrastructure vari-

Table 7-Infrastructure Variables for the Cross-Mode Analysis

\begin{tabular}{lcccc}
\hline & \multicolumn{4}{c}{ Trade Flows via Transport Mode } \\
\cline { 2 - 5 } & Road & Rail & Sea & Air \\
\hline Road infrastructure & road_on_road & road_on_rail & road_on_sea & road_on_air \\
Railroad infrastructure & rail_on_road & rail_on_rail & rail_on_sea & rail_on_air \\
Seaport infrastructure & seaport_on_road & seaport_on_rail & seaport_on_sea & seaport_on_air \\
Airport infrastructure & airport_on_road & airport_on_rail & airport_on_sea & airport_on_air \\
\hline
\end{tabular}

ables are road_on_air, rail_on_air, seaport_on_air, and airport_on_air. It should also be noted that infrastructure indicators are no longer monadic, but dyadic. They indicate the average infrastructure-type-specific quality (or quantity) over the exporting and the importing country.

As outlined above, the variable airport_on_air takes on the logarithm of the average airport quality (or quantity) in the exporting and importing country for observations of the air transport mode. The three variables road_on_air, rail_on_air, and seaport_on_air take on the logarithm of the average road, railroad, or seaport quality (or quantity) for observations of the air transport mode. For observations that are not of the air transport mode, these four variables always take on the value 0 .

Thus, the variable airport_on_air isolates the effect of airport quality (or quantity) on trade via air. Besides this isolated infrastructure trade effect, the regression setup also enables precisely estimating the possible trade effects of improvements in one infrastructure type on trade flows of the other three transport modes (e.g. road_on_air would capture the effect of road infrastructure on trade via air).

As can be seen from previous regressions, the trade effects of distance, contiguity, landlockedness, or being an island, differ over the four transport modes. Consequently, a similar procedure to that used for the infrastructure variables is also used for these four control variables ${ }^{13}$ By so doing, it is possible to disentangle the trade effects of these four control variables over the different transport modes. Moreover, transport mode dummy variables are included in order to account for unobservable and constant differences over different transport modes 14

The results for the infrastructure-quality cross-mode analysis and for a similar analysis based on quantitative infrastructure indicators are presented in Table 8 . It becomes evident that the main results of the previous analyses can be confirmed. Only the density, but not the quality of the road infrastructure can increase road trade, whereas only the quality of the railroad and the airport infrastructure can increase trade via rail or air, respectively. The cross-mode analysis now also suggests that seaport infrastructure quality can significantly increase sea trade flows.

13 The dummy variables for landlocked_MODE and island_MODE take on the value 1 if either the exporter or the importer is landlocked or an island, respectively; otherwise, they are set to 0 .

14 To avoid perfect multicollinearity, the transport mode dummy for the transport mode road is excluded. Thus, the transport mode road serves as the reference category. 
Table 8-Results of the Cross-Mode Analysis

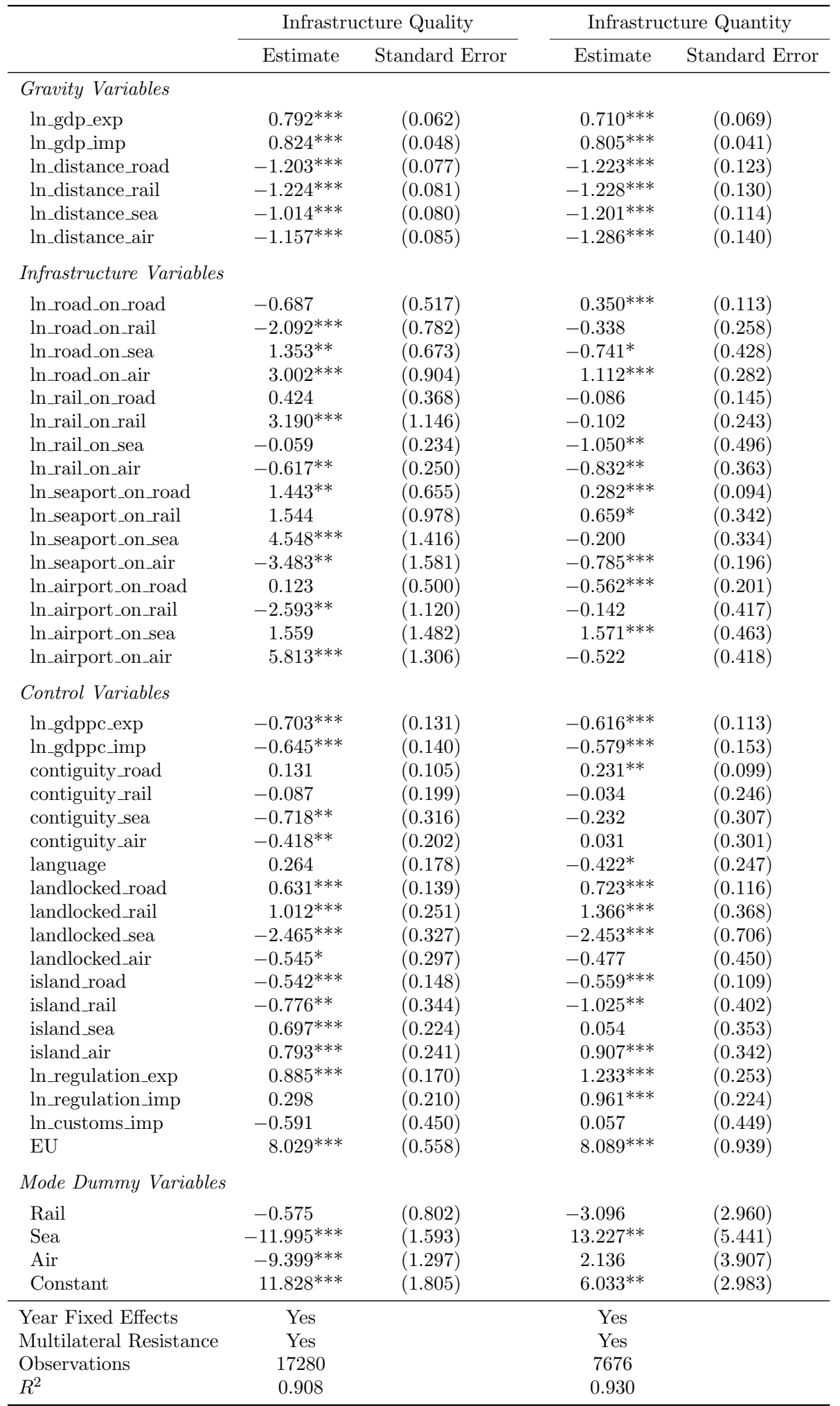

$* \mathrm{p}<0.1, * * \mathrm{p}<0.05, * * * \mathrm{p}<0.01$. Standard errors in parentheses.

Note: The dependent variable is tradeflow. Standard errors are robust and clustered at the country-pair level. Furthermore, observations are automatically excluded from the regression if one of the variables is reported as missing.

Source: Own calculation. 
Especially for quality improvements of rail infrastructure, seaports, and airports, the trade elasticities for the corresponding transport modes are very large and significant.

Although improvements in road infrastructure quality do not increase road trade flows, they appear to decrease rail trade flows and to increase sea and air trade flows. This suggests that road infrastructure quality is an important factor for sea and air trade, two transport modes that require adequate roads for their "firstmile" and "last-mile" logistics. When looking at the road density, there is still a positive relationship with air trade, but there is now a negative relationship with sea trade. Rail trade seems to not be affected by the road density.

In addition to increasing rail trade flows, the quality of the railroad network can also decrease trade via air. This negative relationship also prevails for the railroad density and might thus suggest a competitive relationship between railroad and air trade within Europe. Furthermore, the railroad density negatively affects sea trade flows within the EU.

Both the qualitative and quantitative capabilities of seaport infrastructure can increase trade via road and decrease air trade. Thus, there appears to be a complementary relationship between seaport infrastructure and road trade, and a competitive relationship between seaport infrastructure and air trade. Also, rising quantitative capabilities of seaports can increase rail trade.

The quality of airports can decrease trade via rail, thus suggesting a competitive relationship between airport quality and rail trade. Surprisingly, airport density appears to decrease trade via road and to increase trade via sea.

In addition to these infrastructure variables, the regression coefficients of the control variables for distance, contiguity, being landlocked, and being an island, all take on plausible signs and consequently confirm the validity of the cross-mode regression model.

\section{Discussion}

As established by the regression results, the trade effects of transport infrastructure improvements vary according to the transport infrastructure types. Moreover, these effects vary with respect to the type of infrastructure indicator that is used. Although my analysis does not yield direct conclusions about the reasons for these differences, it can nevertheless serve as a starting point for a discussion on possible mechanisms that might explain these differences.

One main insight from the regression analyses is that the analyzed transport modes are affected differently by quality improvements, compared to quantity improvements. Air and rail trade flows are only affected by quality improvements of the corresponding infrastructure types, whereas road trade, on the other hand, only responds to increases in the road quantity. A possible explanation for these differences can be derived theoretically. Bougheas et al. (1999) assume that infrastructure has positive, but diminishing marginal returns to transport costs. Under this assumption, the regression results could imply that the density of airports and railroads is sufficiently high, but the quality of both infrastructure types offers still room for improvement and could consequently contribute to increasing trade flows of the corresponding transport modes. The quality of roads, on the other hand, appears to be sufficiently high, but road-density improvements can still generate trade increases. These differences should be borne in mind when planning new infrastructure projects. Note, however, that there might be cost 
differences between quality and quantity improvements that should also be considered by governments planning transport infrastructure investments.

The results also highlight the positive spillover effects of transport infrastructure. The spillover effects can accrue to other countries (as can be seen from the transit country infrastructure variables), but also to other transport modes (as can be seen from the cross-mode analysis). It is evident that improvements in the road and railroad infrastructure can lead to increased transit trade flows through the respective country. As the underlying transit routes for the land transport modes of road and rail were derived from the TEN-T corridors, the results emphasize the trade benefits and substantial economic impact of interregional transport networks. To boost its own international trade flows, a country should thus not only aim to improve its own infrastructure, but also press for an improvement of the land infrastructure of countries that lie en route to the major trading partners - or en route to trading partners with whom trade flows should be increased. This in turn raises the question of how to finance such land infrastructure improvements. The results of this study provide evidence that road and railroad improvements in transit countries can also enhance the trading conditions in other trading countries. Consequently, funding should come from all beneficiaries, as is done for the TEN-T corridors, or as done through China's investments in the New Silk Road. Another important insight of this paper is that there are various interdependencies between different transport infrastructure types and transport modes as can be seen from the cross-mode analysis. To the best of my knowledge, the results outlined in Table 8 offer the first comprehensive empirical overview of interdependencies between the four analyzed infrastructure types and trade flows via their corresponding transport modes. It can be seen that improvements in one specific infrastructure type can also have positive or negative spillover effects on other transport modes. For example, higher road infrastructure quality can lead to more sea and air trade due to improved first- and last-mile logistics, but at the same time it can lead to a decrease in rail trade due to competitive forces between the road and the rail transport mode. Moreover, trade flows of one transport mode are often affected by infrastructure types other than just the corresponding one. These outlined interdependencies and spillover effects should therefore be considered by infrastructure planners. They can also serve as a starting point for further research on the trade-enhancing capabilities of infrastructure. It is, for example, not clear whether the outlined trade elasticities refer to induced trade flows or to modal shifts. A regression specification that estimates the effect of an overall transport infrastructure quality indicator on trade flows that are aggregated over all transport modes suggests that the overall quality of transport infrastructure can indeed have export-inducing effects ${ }^{15}$ A reason for potential export-inducing effects is that sufficiently high infrastructure quality could enable firms to export expensive goods that are very sensitive to damage and require timely delivery, two reasons that would prevent these goods from being exported under poorer infrastructural conditions. The results from Coşar and Demir (2016), for example, underline that an increase in the capacity of road capacities can increase a country's ability to participate in global supply chains.

The regression results moreover suggest that exports are more responsive to changes in infrastructure than imports, a finding that confirms the results of

15 This aggregated regression specification is not reported here, but is available upon request. The relevant trade elasticities (standard errors) are: ln_transport_inf_quality_exp: 0.579** (0.249); ln_transport_inf_quality_imp: 0.239 (0.257). 
Francois and Manchin (2013). It is also in line with Celbis et al. (2014), who find that the effect of a country's own infrastructure is greater on its exports than on its imports. Thus, infrastructure improvements appear to induce firms to export their goods much more than they induce customers to import goods or for firms to import intermediate goods. Regarding this finding, it should be borne in mind that the results of this analysis have to be interpreted as short-term effects. It might be realistic to assume that the use of imported intermediates requires companies to extensively change their sourcing strategies or production processes. Changing export regimes, on the other hand, could probably be conducted more quickly. Hence, import effects would materialize in the long, rather than in the short run. Future research could analyze whether long-term effects of transport infrastructure improvements are likely to vary from their short-term counterparts. Also, since we consider intra-EU trade flows where bilateral exports of one EU country are bilateral imports of another EU country, it might seem surprising that export and import effects differ from each other. One reason for this is that eight countries in the sample do not report export flows and consequently only appear as importers. Thus, the set of exporters differs from the set of importers. Moreover, the sectoral composition of a country's exports can differ from the sectoral composition of its imports. As each product might have different requirements concerning its transport, the preferred transport mode can vary over different products. Consequently, the transport infrastructure of a country could be tailored more for either the sectoral composition of exports, which indeed appears more likely and is also indicated by Celbis et al. (2014), or for the sectoral composition of imports, thus causing a difference between export and import effects. Two transport modes that deserve some special attention are waterway and sea trade. Trade via waterways is increased significantly by the quality of port infrastructure within a country. Moreover, a country's waterway density can increase waterway imports. Although these results appear plausible, they should nevertheless be viewed with caution. Only a few countries in the sample trade extensively via waterways, which is why there are many zero trade flows $(71.97 \%)$, and a selection bias could be present.

The results of the different sea trade regressions are often inconclusive or implausible. One reason might be due to the exclusive focus on European trade flows. Within the EU, the average distance between two trading partners is relatively small. Since sea trade is often chosen for relatively long transport routes, the data sample might thus be biased. It should be noted, however, that this argument implies that air trade elasticities should be insignificant as well. Nevertheless, when isolating the effect of seaport quality on sea trade flows in the cross-mode analysis, a significant and strongly positive trade effect is estimated for seaport quality improvements. This could at least indicate that a rising seaport infrastructure quality might increase sea trade flows, as also found by Blonigen and Wilson (2008). Further research is needed to test whether the results would also hold for a more differentiated set of countries.

The analysis also shows that the seaport infrastructure of transit countries does not seem to matter. Improvements in the composition of this variable, for example through the inclusion of hinterland traffic quality, could provide some remedy and might allow for more accurate results. In general, greater data availability for quantitive infrastructure indicators could increase the precision of results. It should also be noted that the herein used quantitative indicators, although they are used regularly in other empirical research papers on transport economics, do 
not specifically differentiate between the quantitative capabilities for the movement of goods versus the quantitative capabilities for the movement of passengers. This is probably most important for the quantitative airport infrastructure variable which indicates the number of commercial airports per $\mathrm{km}^{2}$. Thus, future research could look to improve the meaningfulness of quantitative transport infrastructure indicators in order to further improve the results.

A potential restriction in the analysis is caused by a selection bias in the choice of disaggregated trade data. These were only available for trade flows within the EU and from 2010 to 2017. Given that Portugal-Perez and Wilson (2012) or Donaubauer et al. (2015) have shown that the trade effects of infrastructure improvements are greater for poorer countries, it would thus be interesting to determine whether the results of this study could be upheld in different settings. Furthermore, the underlying trade flow data treat each country as one cohesive geographical entity and do not account for the fact that some goods are not traded directly with the mainland of the country, but with smaller islands or colonies of this country that are, however, not geographically connected to the mainland. For these trade flows, different characteristics would apply than for trade flows with the main land. Although the unique features of these particular trade flows are not accounted for, it can reasonably be argued that the share of such trade flows is very slim and would therefore not distort the main results obtained in the regression analyses.

One inherent problem of these types of analyses is endogeneity. A common approach to mitigating endogeneity concerns is by using lagging infrastructure variables. The main results are robust to lags of three years, thus indicating that endogeneity is not a major problem. It should be noted, however, that lagging infrastructure variables by three years might not be enough, as these variables can be rather stable. Due to data availability, though, it is not in fact feasible to include longer lags. Nevertheless, the results of the strict exogeneity test by Wooldridge (2010) also suggest that endogeneity does not appear to be a significant problem. Consequently, the sensitivity analysis cannot definitely rule out endogeneity, but indicates that causality runs rather from infrastructure to trade, and not the other way round.

\section{Conclusion}

The analysis of disaggregated trade data, in combination with transport-modespecific infrastructure variables, shows that there are indeed differences in the trade effects of improvements in certain types of transport infrastructure. It can be observed that air and rail trade are most responsive to quality improvements in the corresponding infrastructure type. For road trade, positive trade effects can be found for improvements in road density, but not for improvements in road quality. Policymakers should take these trade effect differences into account when calculating the desired benefits of infrastructure projects.

The cross-mode analysis yields interesting insights into the interdependencies between different infrastructure types and transport modes. Improving infrastructure may not only cause trade increases for the corresponding transport mode, but can also have effects on trade via different transport modes. Various competitive and complementary relationships are outlined. These interdependencies should be considered when evaluating future infrastructure investments.

Moreover, the infrastructure of transit countries is a key factor in the determina- 
tion of international trade patterns. The present analysis implies that the TEN-T corridors are crucially important for trade flows using the land transport modes of road and rail, and that improvements in the transit country infrastructure of these two transport modes can lead to substantial trade increases. Consequently, the results confirm the value of interregional infrastructure projects like the TEN$\mathrm{T}$ initiative that can improve transport conditions in important transit countries. Additionally, the estimation results suggest that infrastructure improvements exert a greater impact on exports than on imports, a similar result to Francois and Manchin (2013) or Bottasso et al. (2018). This highlights the importance of creating infrastructural conditions which enable companies to export their products more conveniently and efficiently. Transport infrastructure can therefore play a distinct role in the export performance of a country, which is an important contributor to economic growth and should thus be treated accordingly.

\section{Acknowledgements}

The author would like to thank three anonymous referees, Gernot Sieg, and Kathrin Goldmann for their helpful comments.

\section{REFERENCES}

Alcalá, F. and Ciccone, A. (2004). Trade and Productivity. The Quarterly Journal of Economics, 119(2):613-646.

Alderighi, M. and Gaggero, A. A. (2017). Fly and Trade: Evidence from the Italian Manufacturing Industry. Economics of Transportation, 9(C):51-60.

Anderson, J. E. (1979). A Theoretical Foundation for the Gravity Equation. American Economic Review, 69(1):106-16.

Anderson, J. E. and van Wincoop, E. (2003). Gravity with Gravitas: A Solution to the Border Puzzle. American Economic Review, 93(1):170-192.

Aschauer, D. A. (1989). Is Public Expenditure Productive? Journal of Monetary Economics, 23(2):177-200.

Baier, S. L. and Bergstrand, J. H. (2009). Bonus Vetus OLS: A Simple Method for Approximating International Trade-cost Effects Using the Gravity Equation. Journal of International Economics, 77(1):77-85.

Baldwin, R. and Taglioni, D. (2006). Gravity for Dummies and Dummies for Gravity Equations. NBER Working Papers 12516, National Bureau of Economic Research, Inc.

Bensassi, S., Márquez-Ramos, L., Martínez-Zarzoso, I., and Suárez-Burguet, C. (2015). Relationship Between Logistics Infrastructure and Trade: Evidence from Spanish Regional Exports. Transportation Research Part A: Policy and Practice, 72(C):47-61.

Bergstrand, J. H. (1985). The Gravity Equation in International Trade: Some Microeconomic Foundations and Empirical Evidence. The Review of Economics and Statistics, 67(3):474-81. 
Blonigen, B. A. and Wilson, W. W. (2008). Port Efficiency and Trade Flows. Review of International Economics, 16(1):21-36.

Boarnet, M. G. (1998). Spillovers and the locational effects of public infrastructure. Journal of Regional Science, 38(3):381-400.

Bottasso, A., Conti, M., de Sa Porto, P. C., Ferrari, C., and Tei, A. (2018). Port Infrastructures and Trade: Empirical Evidence from Brazil. Transportation Research Part A: Policy and Practice, 107:126 - 139.

Bougheas, S., Demetriades, P. O., and Morgenroth, E. L. W. (1999). Infrastructure, Transport Costs and Trade. Journal of International Economics, 47(1):169-189.

Buys, P., Deichmann, U., and Wheeler, D. (2010). Road Network Upgrading and Overland Trade Expansion in Sub-Saharan Africa. Journal of African Economies, 19(3):399-432.

Cameron, A. C., Gelbach, J. B., and Miller, D. L. (2011). Robust Inference With Multiway Clustering. Journal of Business 85 Economic Statistics, 29(2):238249.

Canning, D. (1998). A Database of World Infrastructure Stocks, 1950-95. Policy Research Working Paper Series 1929, The World Bank.

Celbis, M. G., Nijkamp, P., and Poot, J. (2014). Infrastructure and Trade: A Meta-Analysis. REGION, 1:25-64.

Cheng, I.-H. and Wall, H. J. (2005). Controlling for Heterogeneity in Gravity Models of Trade and Integration. Review, (Jan):49-63.

Clark, X., Dollar, D., and Micco, A. (2004). Port Efficiency, Maritime Transport Costs, and Bilateral Trade. Journal of Development Economics, 75(2):417-450.

Combes, P.-P. and Lafourcade, M. (2005). Transport Costs: Measures, Determinants, and Regional Policy Implications for France. Journal of Economic Geography, 5(3):319-349.

Coşar, A. K. and Demir, B. (2016). Domestic Road Infrastructure and International Trade: Evidence from Turkey. Journal of Development Economics, $118(\mathrm{C}): 232-244$.

Deardorff, A. (1998). Determinants of Bilateral Trade: Does Gravity Work in a Neoclassical World? In The Regionalization of the World Economy, NBER Chapters, pages 7-32. National Bureau of Economic Research, Inc.

Dollar, D. and Kraay, A. (2003). Institutions, Trade, and Growth. Journal of Monetary Economics, 50(1):133-162.

Dollar, D. and Kraay, A. (2004). Trade, Growth, and Poverty. Economic Journal, 114(493):22-49.

Donaubauer, J., Glas, A., and Nunnenkamp, P. (2015). Infrastructure and Trade: A Gravity Analysis for Major Trade Categories Using a New Index of Infrastructure. Kiel Working Papers 2016, Kiel Institute for the World Economy (IfW). 
Donaubauer, J., Meyer, B. E., and Nunnenkamp, P. (2016). A New Global Index of Infrastructure: Construction, Rankings and Applications. The World Economy, 39(2):236-259.

Duranton, G. (2015). Roads and Trade in Colombia. Economics of Transportation, 4(1):16-36.

Duranton, G., Morrow, P. M., and Turner, M. A. (2014). Roads and Trade: Evidence from the US. Review of Economic Studies, 81(2):681-724.

Early, B. R. (2008). Landlocked and Island States in the International System, 1950-2005. Technical report, Athens, GA: University of Georgia.

Egger, P. and Pfaffermayr, M. (2003). The Proper Panel Econometric Specification of the Gravity Equation: A three-way Model with Bilateral Interaction Effects. Empirical Economics, 28(3):571-580.

Egger, P. and Staub, K. (2016). GLM Estimation of Trade Gravity Models with Fixed Effects. Empirical Economics, 50(1):137-175.

Egger, P. and Tarlea, F. (2015). Multi-way Clustering Estimation of Standard Errors in Gravity Models. Economics Letters, 134(C):144-147.

Eurostat (2016). User Guide on European Statistics on International Trade in Goods. Publications Office of the European Union.

Falvey, R., Foster, N., and Greenaway, D. (2004). Imports, Exports, Knowledge Spillovers and Growth. Economics Letters, 85(2):209-213.

Ferrari, C., Bottasso, A., Conti, M., and Tei, A. (2019). Economic Role of Transport Infrastructure: Theory and Models. Elsevier.

Francois, J. and Manchin, M. (2013). Institutions, Infrastructure, and Trade. World Development, 46(C):165-175.

Frankel, J. A. and Romer, D. (1999). Does Trade Cause Growth? American Economic Review, 89(3):379-399.

Gallego, N., Llano, C., Mata, T. D. L., and DÍaz-Lanchas, J. (2015). Intranational Home Bias in the Presence of Wholesalers, Hub-spoke Structures and Multimodal Transport Deliveries. Spatial Economic Analysis, 10(3):369-399.

Harrison, A. (1996). Openness and Growth: A Time-series, Cross-country Analysis for Developing Countries. Journal of Development Economics, 48(2):419447.

Head, K. and Mayer, T. (2014). Gravity Equations: Workhorse, Toolkit, and Cookbook, volume 4 of Handbook of International Economics, chapter 3, pages 131-195. Elsevier.

Helpman, E., Melitz, M., and Rubinstein, Y. (2008). Estimating Trade Flows: Trading Partners and Trading Volumes. The Quarterly Journal of Economics, 123(2):441-487.

Hummels, D. (2007). Transportation Costs and International Trade in the Second Era of Globalization. Journal of Economic Perspectives, 21(3):131-154. 
Lakshmanan, T. (2011). The Broader Economic Consequences of Transport Infrastructure Investments. Journal of Transport Geography, 19(1):1-12.

Limao, N. and Venables, A. J. (2001). Infrastructure, Geographical Disadvantage, Transport Costs, and Trade. World Bank Economic Review, 15(3):451-479.

Llano, C., De la Mata, T., Díaz-Lanchas, J., and Gallego, N. (2017). TransportMode Competition in Intra-national Trade: An Empirical Investigation for the Spanish Case. Transportation Research Part A: Policy and Practice, 95(C):334355.

Márquez-Ramos, L., Martínez-Zarzoso, I., Pérez-García, E., and Wilmsmeier, G. (2011). "Special Issue on Latin-American Research" Maritime Networks, Services Structure and Maritime Trade. Networks and Spatial Economics, 11(3):555-576.

Martínez-Zarzoso, I., García-Menéndez, L., and Suárez-Burguet, C. (2003). Impact of Transport Costs on International Trade: The Case of Spanish Ceramic Exports. Maritime Economics \& Logistics, 5(2):179-198.

Martínez-Zarzoso, I., Pérez-Garcia, E. M., and Suárez-Burguet, C. (2008). Do Transport Costs Have a Differential Effect on Trade at the Sectoral Level? Applied Economics, 40(24):3145-3157.

Matyas, L. (1997). Proper Econometric Specification of the Gravity Model. The World Economy, 20(3):363-368.

Mayer, T. and Zignago, S. (2011). Notes on cepii's distances measures: The geodist database. Working Papers 25, CEPII.

McCallum, J. (1995). National borders matter: Canada-us regional trade patterns. The American Economic Review, 85(3):615-623.

Melitz, J. and Toubal, F. (2014). Native language, spoken language, translation and trade. Journal of International Economics, 93(2):351 - 363.

Melitz, M. J. and Ottaviano, G. I. P. (2008). Market Size, Trade, and Productivity. Review of Economic Studies, 75(1):295-316.

Micco, A. and Serebrisky, T. (2004). Infrastructure, Competition Regimes, and Air Transport Costs: Cross-country Evidence. Policy Research Working Paper Series 3355, The World Bank.

Moulton, B. R. (1990). An Illustration of a Pitfall in Estimating the Effects of Aggregate Variables on Micro Unit. The Review of Economics and Statistics, $72(2): 334-338$.

Nadiri, M. I. and Mamuneas, T. P. (1994). The Effects of Public Infrastructure and R\&D Capital on the Cost Structure and Performance of U.S. Manufacturing Industries. The Review of Economics and Statistics, 76(1):22-37.

Portugal-Perez, A. and Wilson, J. S. (2012). Export Performance and Trade Facilitation Reform: Hard and Soft Infrastructure. World Development, 40(7):12951307. 
Puga, D. (2002). European Regional Policies in Light of Recent Location Theories. Journal of Economic Geography, 2(4):373-406.

Sánchez, R. J., Hoffmann, J., Micco, A., Pizzolitto, G. V., Sgut, M., and Wilmsmeier, G. (2003). Port Efficiency and International Trade: Port Efficiency as a Determinant of Maritime Transport Costs. Maritime Economics $\&$ Logistics, 5(2):199-218.

Schwab, K. and Sala-i Martín, X. (2017). The Global Competitiveness Report 2017-2018. Technical report, World Economic Forum.

Silva, J. M. C. S. and Tenreyro, S. (2006). The Log of Gravity. The Review of Economics and Statistics, 88(4):641-658.

Tinbergen, J. (1962). Shaping the World Economy; Suggestions for an International Economic Policy. Twentieth Century Fund, New York.

Volpe Martincus, C., Carballo, J., and Cusolito, A. (2017). Roads, Exports and Employment: Evidence from a Developing Country. Journal of Development Economics, 125(C):21-39.

Wilson, J. S., Mann, C. L., and Otsuki, T. (2005). Assessing the Benefits of Trade Facilitation: A Global Perspective. The World Economy, 28(6):841-871.

Wooldridge, J. M. (2010). Econometric Analysis of Cross Section and Panel Data. MIT Press Books. The MIT Press, 2 edition.

Yotov, Y. V., Piermartini, R., Monteiro, J.-A., and Larch, M. (2016). An Advanced Guide to Trade Policy Analysis: The Structural Gravity Model. UNCTAD and WTO, Geneva. 


\section{Appendix - Overview of Variables}

Table A1—Overview of Variables

\begin{tabular}{|c|c|c|}
\hline Variable & Source & Description \\
\hline airport_quality $^{*}$ & GCR & $\begin{array}{l}\text { Variable that indicates the quality of the air transport infrastructure in a country (from } \\
1 \text { to } 7 \text { ). }\end{array}$ \\
\hline airport_quantity* & Eurostat & $\begin{array}{l}\text { Variable that indicates the airport density of a country. Unit: Airports per square kilo- } \\
\text { meter. }\end{array}$ \\
\hline common_colonizer & CEPII & $\begin{array}{l}\text { Dummy variable that indicates whether two countries have had a similar colonizer in the } \\
\text { past (or still have). }\end{array}$ \\
\hline competition $^{*}$ & GCR & $\begin{array}{l}\text { Variable that indicates the quality of local and foreign competition in a country (from } 1 \\
\text { to } 7 \text { ). }\end{array}$ \\
\hline contiguity & CEPII & Dummy variable that indicates whether two countries share a common border. \\
\hline corruption* ${ }^{*}$ & GCR & Variable that indicates the prevalence of corruption within a country (from 1 to 7 ). \\
\hline customs* & GCR & Variable that indicates the quality of the customs procedures in a country (from 1 to 7 ). \\
\hline distance & CEPII & Distance between two trading partners. Measured with the Great Circle Distance. \\
\hline electricity* & GCR & $\begin{array}{l}\text { Variable that indicates the dissemination of electricity and the quality of telephoning } \\
\text { infrastructure in a country (from } 1 \text { to } 7 \text { ). }\end{array}$ \\
\hline$E U$ & Self-made & $\begin{array}{l}\text { Dummy variable that indicates whether both the exporting and the importing country } \\
\text { are members of the EU (Reference date: January 1st of year } t \text { ). }\end{array}$ \\
\hline$G D P^{*}$ & Eurostat & Variable that indicates the GDP of a country. It is denoted in current Euros. \\
\hline$G D P P C^{*}$ & Eurostat & $\begin{array}{l}\text { Variable that indicates the Gross Domestic Product per capita (GDPPC) of a country. } \\
\text { It is denoted in current Euros. }\end{array}$ \\
\hline ict_usage $^{*}$ & GCR & $\begin{array}{l}\text { Variable that indicates the dissemination and quality of ICT usage within a country (from } \\
1 \text { to } 7 \text { ). }\end{array}$ \\
\hline inf & & Placeholder for infrastructure quality or quantity variables. \\
\hline inftrans & & Placeholder for infrastructure quality or quantity variables of transit countries. \\
\hline island $^{*}$ & Early (2008) & Dummy variable that indicates whether a country is an island or not. \\
\hline landlocked ${ }^{*}$ & CEPII & Dummy variable that indicates whether a country is landlocked or not. \\
\hline language & CEPII & Dummy variable that indicates whether two countries share a common official language. \\
\hline legal_system & JuriGlobe & $\begin{array}{l}\text { Dummy variable that indicates whether two countries share a common legal system. } \\
\text { Created on my own. }\end{array}$ \\
\hline$l s c i^{*}$ & UNCTAD & $\begin{array}{l}\text { Variable that indicates seaport quantity. It consists of five components: (1) the number } \\
\text { of ships; (2) the total container-carrying capacity of those ships; (3) the maximum vessel } \\
\text { size; (4) the number of services; and (5) the number of companies that deploy container } \\
\text { ships on services from and to a country's ports. }\end{array}$ \\
\hline property_rights* ${ }^{*}$ & GCR & Variable that indicates the quality of property rights in a country (from 1 to 7 ). \\
\hline public_sector* & GCR & Variable that indicates the functionality of the public sector in a country (from 1 to 7 ). \\
\hline rail_quality* & GCR & $\begin{array}{l}\text { Variable that indicates the quality of the railroad infrastructure in a country (from } 1 \text { to } \\
7 \text { ). }\end{array}$ \\
\hline rail_quantity ${ }^{*}$ & Eurostat & $\begin{array}{l}\text { Variable that indicates the railroad density of a country. Unit: Kilometer per square } \\
\text { kilometer. }\end{array}$ \\
\hline regulation* & GCR & $\begin{array}{l}\text { Variable that indicates the quality of the regulatory environment in a country (from } 1 \text { to } \\
7 \text { ). }\end{array}$ \\
\hline road_quality* ${ }^{*}$ & GCR & Variable that indicates the quality of the roads in a country (from 1 to 7 ). \\
\hline road_quantity* ${ }^{*}$ & Eurostat & $\begin{array}{l}\text { Variable that indicates the motorway density of a country. Unit: Kilometer per square } \\
\text { kilometer. }\end{array}$ \\
\hline seaport_quality* & GCR & Variable that indicates the quality of the port infrastructure in a country (from 1 to 7 ). \\
\hline seaport_quantity* & UNCTAD & $\begin{array}{l}\text { Liner Shipping Connectivity Index (LSCI). Variable that indicates seaport quantity. It } \\
\text { consists of five components: (1) the number of ships; (2) the total container-carrying } \\
\text { capacity of those ships; (3) the maximum vessel size; (4) the number of services; and ( } 5) \\
\text { the number of companies that deploy container ships on services from and to a country's } \\
\text { ports. }\end{array}$ \\
\hline security ${ }^{*}$ & GCR & $\begin{array}{l}\text { Variable that indicates the quality of the business security within a country (from } 1 \text { to } \\
\text { 7). }\end{array}$ \\
\hline surface_area* & WDI & Geographical size of a country. Unit: square kilometers. \\
\hline tradeflow & Eurostat & $\begin{array}{l}\text { Variable that indicates the value of trade flows between two countries. It is denoted in } \\
\text { current Euros and taken from Eurostat. Also, it is disaggregated over transport modes. }\end{array}$ \\
\hline transit_rail_quality ${ }^{* *}$ & Self-made & $\begin{array}{l}\text { Either the average or the minimum value over the rail quality values from all transit coun- } \\
\text { tries that lie en route between the exporting and the importing country. For contiguous } \\
\text { countries, the variable is set to zero. }\end{array}$ \\
\hline transit_road_quality** & Self-made & $\begin{array}{l}\text { Either the average or the minimum value over the road quality values from all transit } \\
\text { countries that lie en route between the exporting and the importing country. For contigu- } \\
\text { ous countries, the variable is set to zero. }\end{array}$ \\
\hline transit_seaport_quality* & Self-made & $\begin{array}{l}\text { The value of the seaport infrastructure quality of the country that serves as the landlocked } \\
\text { country's transit country. If the country is not landlocked, the variable is set to zero. }\end{array}$ \\
\hline transport_inf_quality* & GCR & $\begin{array}{l}\text { Variable that indicates the quality of the transport infrastructure in a country (from } 1 \text { to } \\
7 \text { ). }\end{array}$ \\
\hline value_chain_breadth* ${ }^{*}$ & GCR & $\begin{array}{l}\text { Variable that indicates how broad a country's presence in the global value chain is (from } \\
1 \text { to 7). }\end{array}$ \\
\hline waterway_quantity* & Eurostat & $\begin{array}{l}\text { Variable that indicates the total length of inland waterways (consisting of navigable canals, } \\
\text { rivers, and lakes) within a country. }\end{array}$ \\
\hline
\end{tabular}


Westfälische Wilhelms-Universität Münster, Institute of Transport Economics, Working Paper Series

18 "Residential Parking in Vibrant City Districts"

by Inga Molenda and Gernot Sieg, September 2013

19 "Are commercial ceilings adequate for the regulation of commercial overload on free-to-air TV channels?" by Julia Rothbauer and Gernot Sieg, September 2013

20. "Welfare Effects of Subsidizing a Dead-End Network of Less Polluting Vehicles" by Antje-Mareike Dietrich and Gernot Sieg, October 2013

21. "Costs and benefits of a bicycle helmet law for Germany" by Gernot Sieg, March 2014

22. "Time-Declining risk-adjusted social discount rates for transport infrastructure planning"

by Kathrin Goldmann, April 2017

23. "To pay or not to pay for parking at shopping malls - A rationale from the perspective of two-sided markets"

by Inga Molenda and Gernot Sieg, November 2017

24. "A duopoly of transportation network companies and traditional radio-taxi dispatch service agencies"

by Thorsten Heilker and Gernot Sieg, November 2017

25. “Airport Efficiency in Pakistan - A Data Envelopment Analysis with Weight Restrictions"

by David Ennen and Irem Batool, November 2017

26. "Economic implications of phantom traffic jams: Evidence from traffic experiments" by Kathrin Goldmann and Gernot Sieg, December 2018

27. "Evaluating the Transport-Mode-Specific Trade Effects of Different Transport Infrastructure Types"

by Jan Wessel, February 2019

For a complete list of Working Papers published by Westfälische Wilhelms-Universität Münster, Institute of Transport Economics, please visit the website (http://www.ivmuenster.de) 